\title{
Szemelvények az elmúlt két évtized ELTE-n végzett, medenceléptékú hidrogeológiai kutatásaiból
}

\author{
CZAuner Brigitta, MÁdLnÉ SZŐNYI Judit
}

Eötvös Loránd Tudományegyetem, Általános és Alkalmazott Földtani Tanszék

\section{Short overview of basin-scale hydrogeological research conducted at ELTE in the last two decades}

Abstract

The research and educational activity of the hydrogeological group (József \& Erzsébet Tóth Endowed Hydrogeology Chair) of the Department of Physical and Applied Geology of the Eötvös Loránd University (ELTE, Budapest, Hungary) focuses on the basin-scale system approach of groundwater flow and the related natural phenomena based on the theory of hydraulic continuity. The paper presents this approach with its historical background as compared to the earlier aquiferbased artesian paradigm. The background of basin-scale hydrogeological research approach and methodology under continuous development is shortly explained, while less emphasis is placed on technical minutiae. Among the methods, basin hydraulics are fundamental as these provide the "real groundwater flow system model" based on the basin-scale analysis and interpretation of measured hydraulic data from wells. Accordingly, the basin-scale and particularly the basin hydraulics' results of our research history are reviewed, but the related phenomena investigated by other methods are also mentioned. Our studies covered most areas of Hungary and revealed everywhere the hydraulic continuity of the rock framework and the existence of gravity-driven regional groundwater flow systems irrespectively of the topography and rock type (i.e., siliciclastic or carbonate). The pressure regime in these flow systems is near to hydrostatic, while the flow field is regionally unconfined and recharged from rainwater. In the deeper sub-basins, the gravitational regime is underlain by an overpressured regime (e.g., in the Duna-Tisza Interfluve, Derecske Trough, Békés Basin, Battonya High, Dráva Basin) or underpressured regime (e.g., in the Hungarian Paleogene Basin). Both anomalous pressure regimes are confined with nonrenewable resources (overpressured) or with limited recharge (underpressured). This complex hydraulic situation, as well as the geologic and environmental agency of groundwater flows account for several surface (e.g., salinization, groundwater dependent ecosystems (GDEs)) and subsurface (e.g., hypogene caves, hydrocarbon entrapment) phenomena and processes.

Keywords: groundwater flow, hydraulic continuity, basin hydraulics, gravity-driven flow systems, overpressure, underpressure, flowrelated phenomena

Összefoglalás

Az Eötvös Loránd Tudományegyetem (ELTE) Általános és Alkalmazott Földtani Tanszékének hidrogeológiai kutatóés oktatócsoportja (Tóth József és Erzsébet Hidrogeológia Professzúra) tevékenységének középpontjában a felszín alatti vízáramlásoknak és kapcsolódó jelenségeknek a hidraulikus folytonosság alaptételére épülő medenceléptékű és rendszerszemléletú megközelítése áll. A jelen tanulmány e megközelítést történeti felvezetéssel és a korábbi, rétegtani (hidrosztratigráfiai) alapú ,artézi” paradigmával szembeállítva mutatja be. A folyamatosan fejlesztett medenceléptékú hidrogeológiai kutatási módszertant röviden tárgyaljuk, a technikai részletek helyett kiemelve az alkalmazott módszertani megközelítések magyarázatát. Ezek közül legnagyobb jelentőséggel a kutakban mérhetô hidraulikai adatok medenceléptékú, azaz medencehidraulikai elemzése bír, amelynek eredménye a „valós vízáramlási rendszermodell” felállítása. Ennek megfelelően kutatástörténetünkből a medenceléptékú és különösen a medencehidraulikai eredményeket szemlézzük a továbbiakban, említve az ezek által összefüggésrendszerbe helyezett és egyéb módszerekkel vizsgált jelenségeket is. Az ország területének nagy részét lefedő kutatásaink domborzattól és kőzettípustól (sziliciklasztos vagy karbonátos) függetlenül kimutatták a kőzetváz hidraulikus folytonosságát és a gravitáció vezérelte regionális felszínalatti vízáramlási rendszerek jelenlétét. Ezek medenceléptékben fedetlen, csapadékvízből utánpótlódó és közel hidrosztatikus nyomásrezsimú tartománya alatt a mélymedencékben abnormális nyomásrezsimek (túlnyomásos vagy alulnyomásos) fedett, és nem vagy csak korlátozottan utánpótlódó tartományai találhatók. E komplex hidraulikai helyzettel és a felszínalatti vízáramlások földtani és környezeti hatótényező szerepével számos felszíni (szikesedés, felszín alatti víztôl függő ökoszisztémák, FAVÖKO-k stb.), és felszín alatti (hipogén barlangképződés, szénhidrogén csapdázódás stb.) jelenség és folyamat nyert magyarázatot.

Tárgyszavak: felszín alatti vízáramlások, hidraulikus folytonosság, medencehidraulika, gravitációs áramlási rendszerek, túlnyomás, alulnyomás 


\section{Bevezetés}

Az Eötvös Loránd Tudományegyetem (ELTE) Általános és Alkalmazott Földtani Tanszékének hidrogeológiai kutatócsoportja közel húsz éve foglalkozik a medencebeli felszínalatti vízáramlások és kapcsolódó jelenségek kutatásával. 2016 óta az említett tanszék szervezeti keretein belül múködik a Tóth József és Erzsébet Hidrogeológia Professzúra, mely kutatásaiban geofizikus szakemberekkel is kiegészült. Csoportunk oktatási és kutatási tevékenységének középpontjában a hidraulikus folytonosság (TóTH 1995a,b) alaptételére épülő medenceléptékú megközelítés áll. Ez számos ponton eltér a korábbi, a víztartó rétegeket, a bennük tárolt és belőlük kitermelhető vizet középpontba helyező rétegtani (hidrosztratigráfiai) avagy ,,artézi” megközelítéstől (JIANG et al. 2020). Kutatásaink jelentőségét felértékeli, hogy napjainkban a felszín alatti vízkészletek jelentôsége egyre nô világszerte a népességrobbanás és klímaváltozás nyomán kibontakozó vízválság okán. De hazánkban is egyre inkább előtérbe kerül a felszín alatti térrész sokirányú használata és az igény ennek összehangolására (pl. célzott felszín alatti vízpótlás, talajjavítás, öntözés, csatornázás, szennyezések kontrollálása, szénhidrogén-termelés, geotermikus energiahasznosítás, szén-dioxid-besajtolás, mélységi érckutatás stb.). E feladatok megoldásához elengedhetetlen a felszín alatti vízáramlási rendszerek és múködési mechanizmusaik megismerése és megértése.

A jelen tanulmány célja egyrészt rövid történeti felvezetést követően kiemelni az alkalmazott megközelítések és módszerek újdonságait, másrészt szemelvényesen bemutat- ni a medenceléptékú kutatásaink eddig többnyire angol nyelven közölt főbb eredményeit. Nem törekszünk a téma hazai múhelyekben született eredményeinek szisztematikus áttekintésére, ez ugyanis messze meghaladná e cikk kereteit. Saját kutatásaink leírása is vázlatos, mellyel célunk, hogy felkeltsük az olvasók érdeklődését az eredeti munkák elolvasása iránt. E munkánkkal a Földtani Közlöny 150 éves jubileuma alkalmából tisztelgünk a jeles elődök előtt.

\section{Az artézi paradigmától a medenceléptékú felszín alatti vízáramlási rendszerekig}

Az ,artézi mechanizmus” a hidrogeológia elsô egységes - empirikusan levezetett - paradigmája (JIANG et al. 2020), mely a mélyfúrásos feltárásnak köszönhetôen született meg és a XIX. század folyamán vált általánosan elfogadottá. Az artézi szó két vízzáró réteg közötti vízvezető rétegben tárolt vizet jelent, a föld felszíne fölé emelkedő vízszinttel. Fogalomhasználata szerint a talajvíz a legfelsố vízzáró réteg fölött helyezkedik el és csapadékból utánpótlódik. A rétegvíz két vízzáró réteg közötti vízvezető (permeábilis) rétegben tárolt vizet jelent. A rétegvíz a réteg felszíni kibukkanásánál pótlódik a csapadékvízből, míg vízszintje a vízvezetô bármely pontján fúrt kútban a felszíni kibukkanás vízszint magasságáig emelkedik. Ha ez a felszín fölé szökő vizet ad, akkor artézi vízről beszélünk (1.a ábra).

Ez a nézetrendszer a „hidraulikus folytonosság” felismerésével vált túlhaladottá a XX. század második felétől kezdődően (1.b ábra). A hidraulikus folytonosság a kőzet-
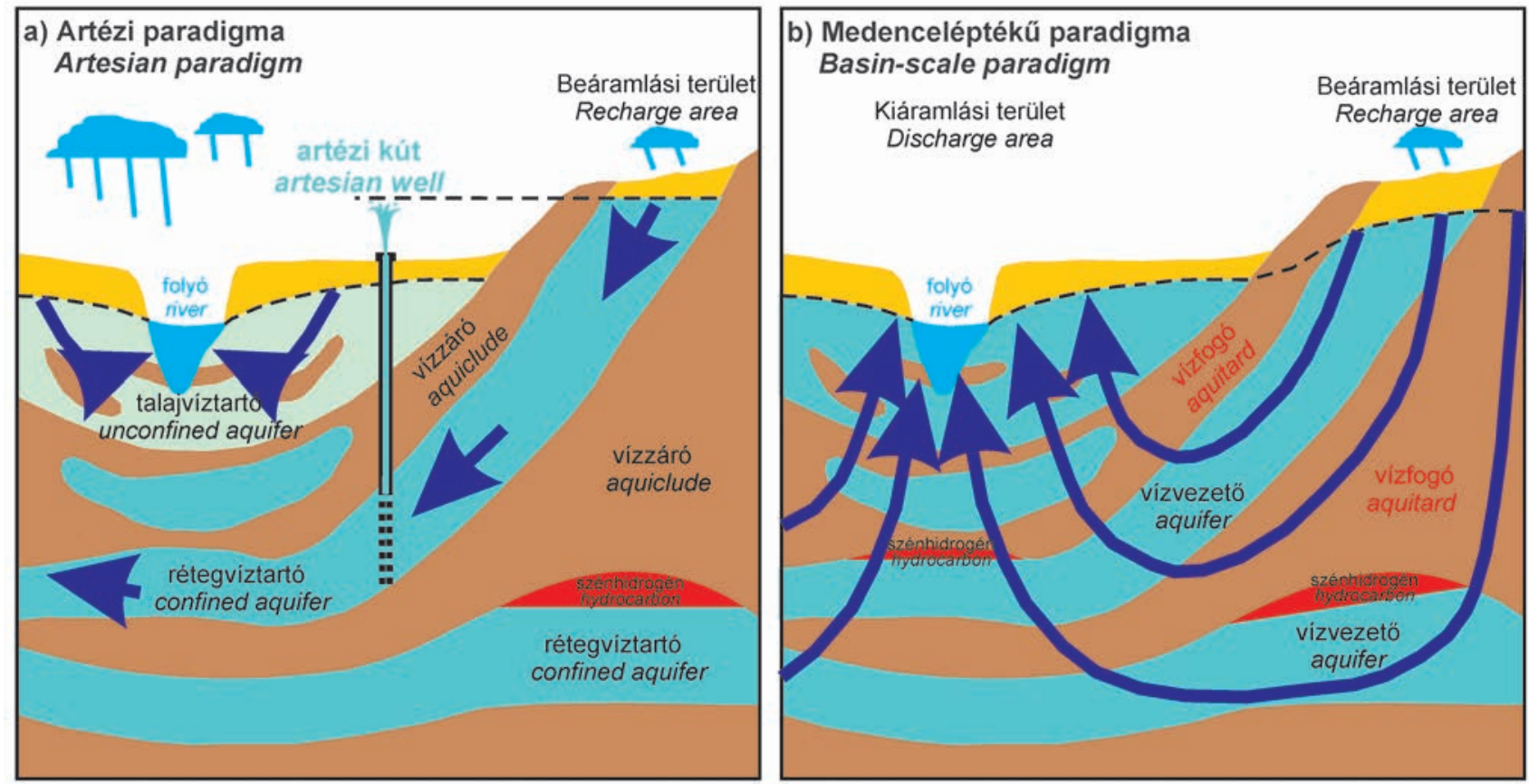

1. ábra. Az a) elkülönült víztartókra épülő artézi paradigma és a b) medenceléptékű, vízvezetők és vízfogók vertikális kapcsolatain alapuló, rendszerszemléletủ hidrogeológia összevetése

Figure 1. Comparison of a) the separated aquifer-based artesian paradigm and b) the basin-scale system approach of hydrogeology based on the vertical connections of aquifers and aquitards 
vázban tározott víznek az a tulajdonsága, hogy nyomásának (hidraulikus emelkedési magasságának) tetszőleges pontban bekövetkezô megváltozása más pontokban is megváltoztatja a víz nyomását (hidraulikus emelkedési magasságot) (TóTH 1995a,b). A hidraulikus kapcsolatok természetes hatásokra (térfelszín magasság különbségei, éghajlati körülmények vagy erózió/üledékképződés) és emberi beavatkozások eredményeként (szivattyúzás) is kialakulnak. Ugyanakkor mivel a pórusvízben fellépő nyomásváltozások a kőzetvázban véges sebességgel terjednek annak áteresztőés/vagy tárolóképessége függvényében, így a hidraulikus folytonosság észlelését megnehezíti a túl nagy távolság, a túl rövid megfigyelési idő. De akadályozhatja az is, ha a víz kémiai összetételében, hômérsékletében, izotópösszetételében, korában stb. bekövetkező jelentősebb változások egybeesnek a vízrekesztô képződmények határfelületeivel. Ezeknek a hidraulikus folytonosságot elfedő tényezóknek köszönhetően a folytonosság felismerése, valamint ebből következően a fogalomrendszer átalakulása és teljes átértése sok helyen még napjainkban is zajlik.

\section{A hidraulikus folytonosság felismerése és következményei}

Elsőként CHAMBERLAIN (1885) írta le, hogy „,tökéletesen vízzáró rétegek nincsenek", s már MUNN (1909) is a rétegek vízzáróságát „hagyományokon alapuló tévhit”-nek minősítette. Jóval később sikerült ezeket az állításokat mért permeabilitás értékekkel is alátámasztani (BRACE 1980, NEUZIL 1994). Ugyanakkor „,indirekt” bizonyítékokkal a hidrogeológia két, egymással párhuzamosan fejlődő irányzata is szolgált. A „mérnöki” irányzat vízadó vagy kúthidraulikai (helyi próbaszivattyúzási-) vizsgálatainak eredményeként az „ideálisan zárt vízadó réteg” helyére a „többrétegú vízadó" lépett (pl. HANTUSH \& JACOB 1955; HANTUSH 1956; NEUMANN \& WhitersPoOn 1969a,b, 1972; HALÁSZ 1975; SzÉKELY 1977). A ,tudományos” hidrogeológiai irányzat regionális vízkészlet-kutatási eredményei rávilágítottak, hogy a hosszú idejű próbaszivattyúzások, regionális nyomáseloszlások, az egész medencére kiterjedő vízmérlegek és nagy léptékú áramlási modellek számszerú értékelése csak a regionális és az egyes képződményeken túlmutató hidraulikus folytonosság feltételezésével lehetséges (pl. WALTON 1960; Tóth 1963, 1978; FREEZE \& WitHERSPOON 1966, 1967, 1968; MARTON \& SZANYI 2000; SZANYI 2004; MARTON 2009). Végeredményben tehát a hidrogeológia ,mérnöki” és „tudományos” irányzata is felismerte egymástól függetlenül a medenceléptékú, regionális hidraulikus folytonosságot. Ezzel megkezdődhetett a két irányzat közeledése, mely folyamat eredménye egy új, medencékben gondolkodó hidrogeológiai szemlélet kialakulása lett. Mi is ennek a jelentősége? Felismertük (i) a folyadékok általános jelenlétét a földkéregben, (ii) a medenceléptékú vízáramlási rendszereket, (iii) a kőzet-víz kölcsönhatás révén a folyadékok és áramlásuk mint földtani hatótényezők jelentőségét valamennyi földtani folyamatban, (iv) a kôzetváz deformációja által okozott tranziens áramlási viszonyokat, (v) a tér- és időskálák teljes spektrumában való gondolkodás jelentőségét, (vi) ezáltal a gyakorlati problémák okainak és megoldásainak (regionális) térbeli és (földtörténeti) időbeli léptékben történő kezelésének szükségességét.

Természetesen ezek a felismerések nem jelentették azt, hogy a változás mindenhol egyszerre és egy időben bekövetkezett, sokkal inkább egyes kutatók és nemzetközi kutatócsoportok (többek között az USA, Kanada, Kína, Mexikó, Ausztrália, Japán, Hollandia, Kolumbia és közöttük Magyarország) tették azt magukévá. 2011 óta a Hidrogeológusok Nemzetközi Szövetsége (IAH) Regionális Vízáramlási Bizottsága (RGFC) fogja össze a témában zajló kutatókat, és szorgalmazza világszerte a medenceléptékú szemlélet elterjedését és a vízáramlási rendszerek kutatását, elméleti és gyakorlati téren egyaránt.

\section{A medencebeli vízáramlások rövid nemzetközi történeti áttekintése}

A hidraulikus folytonosság fennállásának meghatározó következménye a kiterjedt medencebeli felszín alatti vízáramlási rendszerek felismerése. Ezek hajtóeróinek, térbeli mintázatának és kontrolláló tényezőinek spekulatív értékelése már a XX. század elejétől felmerült. Elsőként KING (1899) ismerte fel, a felszín alatti vizek felsô határfelületét képezô talajvíztükör domborzata nagyjából a földfelszínt követi. Továbbá a csapadékból utánpótlódó felszín alatti vizek a domborzati magaslatoktól a mélyedések felé áramlanak, majd a völgyek felszíni vízfolyásait táplálva csapolódnak meg. A formációkon keresztüli vízáramlást elsôként MuNN (1909) feltételezte. A legkorábbi elképzelést hierarchikus eloszlású felszín alatti vízáramlási rendszerekról FOURMARIER (1939) publikálta.

A vízáramlási rendszerek adatfeldolgozáson nyugvó és korszerú matematikai leírásához szükséges alapot HUBBERT (1940) klasszikus tanulmánya teremtette meg. Ebben bevezette a folyadékpotenciál (az egységnyi tömegú folyadékra jutó összes mechanikai energia mennyisége) fogalmát a vízföldtanba. Továbbá rámutatott annak összefüggésére a kutakban mérhető hidraulikus emelkedési magassággal (ahol $g$ gravitációs állandó, $h$ hidraulikus emelkedési magasság). Ezáltal a hajtóerőtér (nagysága és iránya - a folyadék a nagyobbtól a kisebb folyadékpotenciálú pont felé áramlik) kiszámíthatóvá és modellezhetôvé vált. A hidraulikus hajtóerőt a kôzetváz hidraulikai tulajdonságaival (permeabilitás, hidraulikus vezetôképesség, tározás) kombinálva (DARCY, 1856) az áramtér (áramlási irányok és intenzitások) is leképezhetővé vált. HUBBERT (1940) folyadékpotenciál fogalomra alapozott felszín alatti áramképén KING (1899) felismeréseiből kiindulva a talajvíztükör domborzata nagyjából a földfelszínt követi és a felszín alatti víz csak a völgyekben csapolódik meg.

Annak felismerése, hogy a megcsapolódás völgyekben koncentrálódása hibás posztulátum, TóTH József magyar származású kanadai hidrogeológus professzor nevéhez fúződik. TóTH $(1962,1963)$ tanulmányaival kezdődött a hidrogeológia ma már „Tóth-féle forradalom”-ként (BREDEHOEFT 2018) emlegetett korszaka, mely a „medenceléptékú hidrogeológia" kialakulásához vezetett. Ezekben TóTH a HuB- 
BERT (1940) által bevezetett folyadékpotenciál fogalmát elsőként alkalmazta medenceméretú vízáramlási folyamatok matematikai leírására. A stacioner vízáramlást leíró Laplace-egyenletet analitikusan oldotta meg a kétdimenziós egyszerû medence (,unit basin”) és a kis vízgyújtő vagy összetett medence (,,composite basin”) geometriai viszonyai és homogén-izotróp közeg feltételezése mellett. Az egyszerû medencében felsô peremfeltételként a topográfiát követő talajvíztükröt alkalmazta lineáris lejtéssel, míg a medence oldalai szimmetriai okokból, az alja pedig idealizált impermeábilis határ. A számított folyadékpotenciál-értékekből az egyszerú medencében egy áramlási rendszer rajzolódik ki, melyben a megcsapolódás már nemcsak a völgyben koncentrálódik, hanem a medence teljes alsó szakaszán jelentkezik a felszínen is (2. ábra). Az „egységmedenceként" ismertté vált áramképen belül három különböző hidraulikai rezsimjellegû területet és medencerészt különített el, amelyek eltérô hidraulikai paraméterekkel jellemezhetôk. Ezek a beáramlási (utánpótlódási), átáramlási és kiáramlási (megcsapolódási) területek, illetve medencerészek. Ebből adódóan ,artézi” vízviszonyok homogén kőzetvázú egységmedencében is kialakulhatnak annak kiáramlási területén. Ez pedig a mélységgel növekvő hidraulikus emelkedési magasság és nem a vízzáró rétegek jelenlétének következménye (JIANG et al. 2020). Az összetett medence (TóTH 1963) felszíne már egy a valósághoz közelebb álló, szinuszos függvénnyel írható le, míg az ezt nagyjából követô vízszint hierarchikusan fészkelt áramlási rendszereket hoz létre, melyek különböző léptékú típusai a lokális, intermedier és regionális áramlási rendszerek (2. ábra).

Már az egység- és összetett medence összehasonlítása alapján megállapítható, hogy a valós medencék felszín alatti vízáramlási képe az egységmedence környezeti hatások miatt módosult változataként fogható fel. Az elméleti megoldás valós hidrogeológiai helyzetekre történő alkalmazására Tо́тн maga is utalt korai munkáiban a „hidrogeológiai környezet" (domborzat, klíma, földtani felépítés) és a felszín alatti vízrezsim ok-okozati összefüggésrendszerének bevezetésével (TóTH 1970). A környezeti körülmények megváltozásának hatására az áramlási rendszerek tranziens állapotba kerülnek, és megkezdődik átalakulásuk (pl. TóTH \& MILLAR 1983, HAVRIL et al. 2016, SzIJÁRTó et al. 2019b). Amenynyiben ilyen változásokkal nem számolunk vizsgálataink során, akkor medenceléptékben feltételezhető a kvázi stacioner vízáramlási helyzet, azaz az áramlási pályák viszonylagos ,állandósága”. Emiatt a víz és a kőzetváz tartós kölcsönhatásba kerülnek egymással, és ennek következtében a víz mint földtani hatótényezô valamennyi felszín alatt

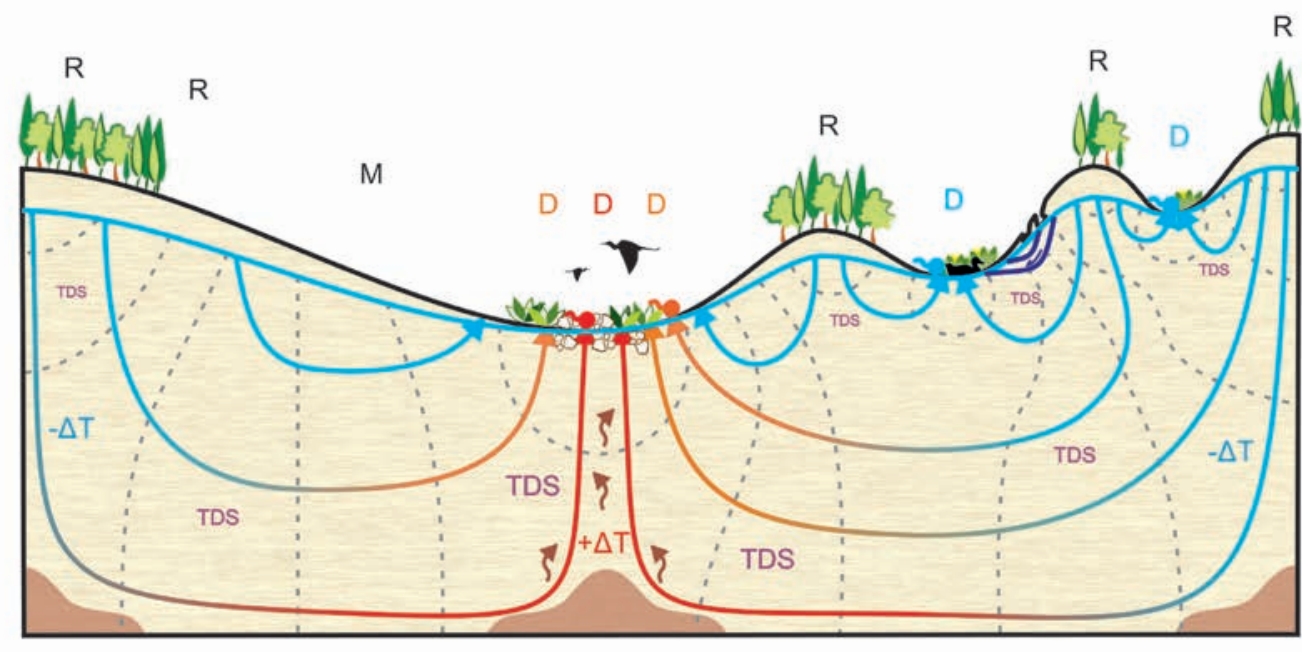

\begin{tabular}{|c|c|c|c|}
\hline & $\begin{array}{l}\text { viztükör } \\
\text { water table }\end{array}$ & $\mathrm{R}$ & $\begin{array}{l}\text { beáramlási terület } \\
\text { recharge area }\end{array}$ \\
\hline & $\begin{array}{l}\text { ekvipotenciális vona } \\
\text { equipotential line }\end{array}$ & ${ }^{\mathrm{al}} \mathrm{M}$ & $\begin{array}{l}\text { átáramlási terület } \\
\text { midline area }\end{array}$ \\
\hline & $\begin{array}{l}\text { áramvonal } \\
\text { streamline }\end{array}$ & D & $\begin{array}{l}\text { hideg kiáramlási terület } \\
\text { cold discharge area }\end{array}$ \\
\hline & $\begin{array}{l}\text { hideg forrás } \\
\text { cold spring }\end{array}$ & D & $\begin{array}{l}\text { langyos kiáramlási terület } \\
\text { lukewarm discharge area }\end{array}$ \\
\hline & $\begin{array}{l}\text { langyos forrás } \\
\text { lukewarm spring }\end{array}$ & D & $\begin{array}{l}\text { meleg kiáramlási terület } \\
\text { thermal discharge area }\end{array}$ \\
\hline & $\begin{array}{l}\text { termálforrás } \\
\text { thermal spring }\end{array}$ & $-\Delta T$ & $\begin{array}{l}\text { negativ hömérsékleti anomália } \\
\text { negative temperature anomaly }\end{array}$ \\
\hline & $\begin{array}{l}\text { sókiválás } \\
\text { saline precipitate }\end{array}$ & $+\Delta T$ & $\begin{array}{l}\text { pozitiv hömérsékleti anomália } \\
\text { positive temperature anomaly }\end{array}$ \\
\hline
\end{tabular}

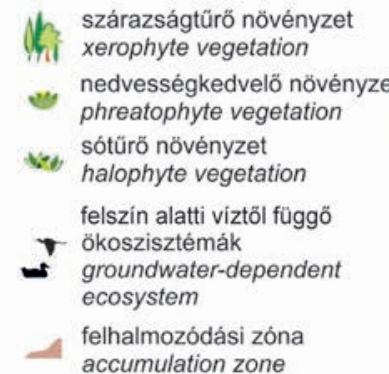

accumulation zone

$\mathrm{R}$ 
zajló folyamatban szerepet játszik. E folyamatok és a hatásukra kialakuló jelenségek rendkívül szerteágazóak az ásvány-és szénhidrogéntelepek képződésétől a barlangok kialakulásán, biogeokémiai kiválásokon, ökoszisztémákon és a geotermális jelenségeken át egészen a tektonikai mozgásokig (pl. TóTH 1999, INGEBRITSEN et al. 2006, KLIMCHOUK 2007, Tóтн 2009a, ERŐss et al. 2012a, Kovács-BodOR et al. 2018). Ez egyúttal felkínálja a felszín alatti víz- és fluidumáramlások közvetett, az általuk okozott földtani és környezeti jelenségek megértésén alapuló kutatási lehetőségét.

Más szerzốk arra is felhívták a figyelmet, hogy a vízszintkülönbségek (azaz atopográfiai hajtóerô) mellett egyéb hajtóerôk (pl. kompakció, tektonikus kompresszió, hőmérséklet- vagy sótartalom-különbségből adódó felhajtóerő) szerepével is számolni lehet, különösen az aktívan deformálódó üledékes medencékben (GARVEN 1995, INGEBRITSEN et al. 2006, Simmons et al. 2001). Azonban ezek megértésében is alkalmazhatók a vízszintkülönbségek által vezérelt áramlási rendszerekre kidolgozott megközelítések és módszerek.

Napjainkban a modern hidrogeológia differenciálódása, azaz más tudományterületekre specializált ágazatainak (pl. olaj-, környezeti, öko-, városi, paleo-hidrogeológia) kialakulása (DEMING 2002) zajlik. De az elmélet fejlődése is nyomon követhető, így számos olyan tanulmány napvilágot látott az utóbbi években, amelyek a vízszintkülönbségek által vezérelt vízáramlási rendszerek mechanizmusainak és jellemzőinek jobb megértését célozták analitikus módszerekkel (pl. JIANG et al. 2011, WANG et al. 2017, ROBINSON \& LOVE 2014) vagy a numerikus szimuláció eszközeivel (pl. GLEESON \& MANNING 2008, CARDENAS \& JIANG 2010, JiANG et al. 2010, ZHOU \& Li 2011 stb.). Az elméleti fejlődés eredményeképpen mára a medencebeli vízáramlásokat földfelszín alatti energiaáramlási rendszereknek tekintik (ENGELEN 2013), azaz tágabb értelmezésben a transzport rendszerek közé sorolják (ZıJL 1999), melyek nagyobb viszkozitású folyadékáramlási rendszerekre szuperponálódnak (ZIJL 2019). E felismeréseknek köszönhetően a hidrogeológia a dinamikus folyamatok medenceléptékú megértésének korszakába lépett, követve a földtudományokban, a meteorológiában, az óceanológiában bekövetkezett fejlődést (BREDEHOEFT 2018).

\section{A kérdéskör gyakorlati jelentősége}

Mindennek a gyakorlati jelentősége különösen kiemelkedő napjainkban, amikor a felszín alatti vizek fontossága egyre nô a népességrobbanás és klímaváltozás nyomán kibontakozó globális vízválság révén. A medenceléptékú és az összefüggések megértésén alapuló hidrogeológia innovatív, rendszerszemléletú és fenntartható megoldásokat kínál (ld. IAH 2020) a szúk értelemben vett hidrológiai és hidrogeológiai kérdéseken, a vízkincsek felkutatásán és védelmén túl számos más területen is. Így környezetvédelmi, területtervezési, szikesedési, erdő- és mezőgazdasági, valamint ökológiai kérdések tudományos igényư kezeléséhez is. Ezen túlmenően új szemléletű megközelítéseket ígér a geotechnikai (pl. szén-dioxid-besajtolás), geotermikus, ásványfeltárási (pl. mélységi érckutatás) és szénhidrogén kutatási megoldásokhoz.

\section{A magyarországi paradigmaváltás fóbb lépései röviden}

A hazai hidrogeológusok az 1950-1960-as években kezdték a kutakban mért vízszintadatok feldolgozását felszín alatti vízáramlási rendszerek térképezésére használni (SZEBÉNyi 1955, 1965; SCHMIDT Eligius \& AlMÁSSY 1962; URBANCSEK 1963; RÓNAI 1963). Ezek az empirikus tanulmányok felismerték a topográfiai magaslatok és mélyedések, a vízáramlás vertikális komponense és a hőmérsékleteloszlás közti összefüggést, sekély mélységre (max. 400 m) korlátozódva.

TóTH József professzor RóNAI (1963) tanulmánya nyomán ismerte fel, hogy áramlási rendszer elmélete az Alföldre is alkalmazható. Kapcsolatfelvétele a magyarországi hidrogeológusokkal 1963-as, RóNAI Andrásnak írott levelével kezdődött. Késôbb már ERDÉLYI Mihály tartotta fontosnak, hogy elküldje TóTHnak a Pannon-medence hidrodinamikájáról 1971-ben készült tanulmányának (ERDÉLYi 1976) kéziratát. Ebben mért adatok feldolgozásával igazolta TóTH gravitációs vízáramlási rendszer modelljének fennállását az Alföldön, s egyúttal az alföldi kvarter vízadó és vízfogó képződmények egyetlen nagy rétegzett víztartó rendszerként történő viselkedését (levelezések adatait ld. MÁDL-SzŐNYI 2008). Keresztszelvényeinek logaritmikus skálájú vertikális tengelyével a sekélyebb mélységek gravitációs áramlási mintázatát hangsúlyozta. A mélységi túlnyomás eredetének és eloszlásának kérdéseivel azonban nem foglalkozott.

Az új, ,rétegzett víztartó rendszer” avagy „hidraulikus folytonosság" szemléletet az 1970-80-as évektől többen alkalmazták (MARTON 2012) matematikai (HALÁsz 1975), hidrogeológiai (RóNAI 1975, 1985), kúthidraulikai (SzÉKELY 1977) és izotóphidrológiai (PAPP 1974, MARTON \& Mikó 1989, STUTE \& DEÁK 1989) alátámasztást szolgáltatva annak.

TóTH József professzor 1994-től kapcsolódott be személyesen a hazai hidrogeológiai oktatásba és kutatásba. Az ELTE Általános és Alkalmazott Földtani Tanszékén, MÁDLNÉ SzŐNYI Judit vezetésével és TóTH József személyes közremúködésével (ELTE, címzetes egyetemi tanár) elinduló képzés és iskolateremtés nyomán a hidrogeológiai csoport (2016 óta Tóth József és Erzsébet Hidrogeológia Professzúra) a 2000-es évektől már nemzetközi érdeklődésre számot tartó kutatásokat indított. Ezek mindegyike a Pannon-medence - mint természetes „,kutatólaboratórium” felszín alatti vízáramlási rendszereinek megértését célozta.

Az Alföld regionális áramlási rendszereinek, valamint a mélységi túlnyomás eredetének és eloszlásának vizsgálatára elsôként ALMÁsi (2001) PhD-dolgozatában és TóTH \& ALMÁSI (2001) publikációjában vállalkozott. Az egész Alföldre nagyjából 3000 m mélységig kiterjedően mintegy 16000 folyadékpotenciál-adat szisztematikus medencehidraulikai feldolgozását végezték el. A hidraulikai adatfeldolgozás értelmezéséhez elsôként végezték el az Alföld neogén képződményeinek regionális hidrosztratigráfiai tagolását a következők szerint: Preneogén képződmények (hidraulikus vezetôképesség, $\mathrm{K}=10^{-5} \mathrm{~m} / \mathrm{s}$ ), Prepannóniai Vízvezető (pannóniainál idősebb neogén képződmények, $\mathrm{K}=10^{-6} \mathrm{~m} / \mathrm{s}$ ), 
Endrődi Vízfogó (Endrődi Márga Formáció, $\mathrm{K}=10^{-9} \mathrm{~m} / \mathrm{s}$ ), Szolnoki Vízvezető (Szolnoki Homokkő Formáció, K=10-7 $10^{-6} \mathrm{~m} / \mathrm{s}$ ), Algyői Vízfogó (Algyői Formáció, $\mathrm{K}=10^{-8}-10^{-7}$ m/s), Nagyalföldi Vízvezető (Algyői Formációnál fiatalabb képződmények, $\mathrm{K}=10^{-5} \mathrm{~m} / \mathrm{s}$ ). Tanulmányukban két különböző hajtóeró által vezérelt folyadékáramlási rezsimet különítettek el. Egy felső, a földfelszín eleváció különbségei által vezérelt (gravitációs) rezsimet és egy, az előbbit hidraulikusan alátámasztó, tektonikai kompresszió által vezérelt (AlMÁsi 2003) (túlnyomásos) rezsimet. Megállapították, hogy a gravitációs rezsim normál nyomásállapotú, regionálisan fedetlen, és csapadékból utánpótlódik, míg a kompressziós rezsim túlnyomásos (1-35 MPa többletnyomás) és regionálisan fedettnek tekinthető. A két rendszer közti átmenet üledékes ablakokon és vezető vetôkön keresztül valósul meg. Az azonosított folyadékpotenciál-anomáliák szénhidrogén csapdázódásban betöltött szerepét is elemezték (AlmÁSi 2001, TótH 2003).

Végeredményben ezek a nagyszabású, mért adatokon nyugvó munkák az új paradigma további hazai alkalmazási és fejlesztési lehetôségeinek útját is megnyitották számos hazai hidrogeológiai múhelyben. Többek között vízkémiai-izotóphidrogeológiai (VARSÁNYI 2000, VARSÁNYI \& Ó. KovÁCS 2009), geomatematikai (MARTON \& SZANYI 2000), numerikus modellezési (SZANYI 2004), vízbázisvédelmi és geotermikusenergia-hasznosítási (TóTH et al. 2016, Szốcs et al. 2018) és számos, itt külön nem említett területen és munkában.

Jelen tanulmány céljaival összhangban a továbbiakban az ELTE hidrogeológiai kutatócsoportjának az elmúlt két évtizedben Magyarország területére vonatkozó, többnyire csak angol nyelven publikált medencehidraulikai eredményeinek szemelvényes bemutatására törekszünk. Ugyanakkor megjegyezzük, hogy bár itt nem tértünk ki rá, de a hazai intézmények hidrogeológus kutatói ugyanebben az időszakban számos munkában és tanulmányban alkalmazták a medencehidraulikai közelítést és gazdagították a Pannonmedencére vonatkozó eredményeket. Kutatásaink bemutatását megelőzóen a medencehidraulikai megközelítést és módszertant vázoljuk.

\section{Medenceléptékú hidrogeológiai módszertan}

Az alkalmazott módszertan rövid tárgyalására azért van szükség, mert a medencehidraulikai feldolgozásokban a víztartó rétegekre használt (,artézi”) megközelítéshez képest eltérô módon, a hidraulikus folytonosság elvéből kiindulva végezzük az elemzéseket. Ennek értelmében minden kőzetnek van valamennyi permeabilitása, így medenceléptékben nem számolhatunk tökéletes vízzárók jelenlétével (DEMING 2002), csak a modellezések során (matematikai értelemben) a határfeltételek megadásánál. Így a medenceléptékú vizsgálatokban a cél a víz útjának megismerése. Ez pedig a medencét felépítő vízvezető és vízfogó egységek hidraulikai kapcsolataitól függ. Mindezekből az is következik, hogy medenceléptékú (terület:1000-10 000 km², mélység: több 1000 m) összefüggések hatást gyakorolnak nemcsak a regionális léptékú, de a felszín alatti vizek lokális folyamataira is. Így lokális kérdéseket is célszerû a medenceléptékú kutatás eredményeibe ágyazva értékelni.

Egy munkafolyamatot dolgoztunk ki a felszín alatti vízáramlási rendszerek medenceléptékú vizsgálatára (3. ábra). Ez részben TóTH (2009) módszertanán alapul, melyet saját kutatási tapasztalataink alapján továbbfejlesztettünk. A tapasztalatokon nyugvó kutatási munkafolyamat az elvégzett fázisok visszacsatolásai révén újraindítható. Ezzel biztosítja a hipotézisek, adatfeldolgozások és modellek, és ezáltal a kutatási eredmények folyamatos fejlesztését és megújítását. A munkafolyamat alapsémája további módszerekkel és kimenetekkel bővíthető.

A munkafolyamat elsô lépéseként a vízáramlási rendszerekhez kapcsolódó földtani és környezeti jelenségek és folyamatok retrospektív (3. ábra/l) és jelenlegi állapotának (3. ábra/2) vizsgálata zajlik, ami megalapozza az előzetes „hipotézis vagy koncepcionális vízáramlási modellt”. A következő lépés a hidrosztratigráfiai értelmezés (3. ábra/3). A munkafolyamatban a legnagyobb hangsúllyal szereplő központi elem a kutakban mérhető hidraulikai adatok medenceléptékú, azaz medencehidraulikai elemzése (3. ábra/4), melyet kiegészíthet a kutak vízkémiai és hőmérsékleti adatainak feldolgozása (3. ábra/5). A medencehidraulikai eredményeket a hidrosztratigráfiával kombinálva felállítható a „valós vízáramlási rendszermodell”. Ezt úgy értelmezhetjük, mint az adott terület vízáramlási rendszereit az elérhetó valós adatok háromdimenziós medencehidraulikai feldolgozása és rendszerszerú értelmezése alapján leíró modellt. A kezdeti ,hipotézis vagy koncepcionális modell” a medencehidraulikai értelmezés „,valós vízáramlási rendszermodellje" által nyerhet megerósítést vagy akár cáfolatot. A vízkémiai és hőmérsékleti adatfeldolgozás (3. ábra/5) eredményei visszacsatolhatók a vízáramlási rendszerek által előidézett jelenségekhez, így az 1. és 2. lépésben (3. ábra/1,2) értékelt jelenségekkel együtt a ,valós vízáramlási rendszermodell” révén nyerhetnek értelmezést. De megfordítva felhasználhatók recens és múltbéli, a vízáramlásokhoz köthetô jelenségek értelmezésére (például a nyersanyag és geotermikus energia kutatásában). Végül a numerikus áramlás és transzport modellezés (3. ábra/6) a valós rendszer ismerete és megértése, azaz a medencehidraulikai elemzés után következhet, mivel annak absztrakciójaként tekinthető. Ez az absztrakció teszi lehetővé a medenceléptékben meghatározó folyamatok megragadását a numerikus szimuláció révén. De látjuk a 3. ábra alapján, hogy bemenő adatait és validációját a munkafolyamat során felállított és értelmezett adatrendszerekből nyeri.

\section{Retrospektív kutatás, vízáramlási jelenségek és folyamatok}

A felszín alatti vízáramlási rendszerek felszínen nyomozható környezeti következményeinek (hidrológiai, talajtani, növénytani, szállítási, felhalmozási, geomorfológiai stb. jelenségek (TóTH 1999)) vizsgálata egyrészt a jelenségek és folyamatok recens terepi lenyomatainak térképezé- 


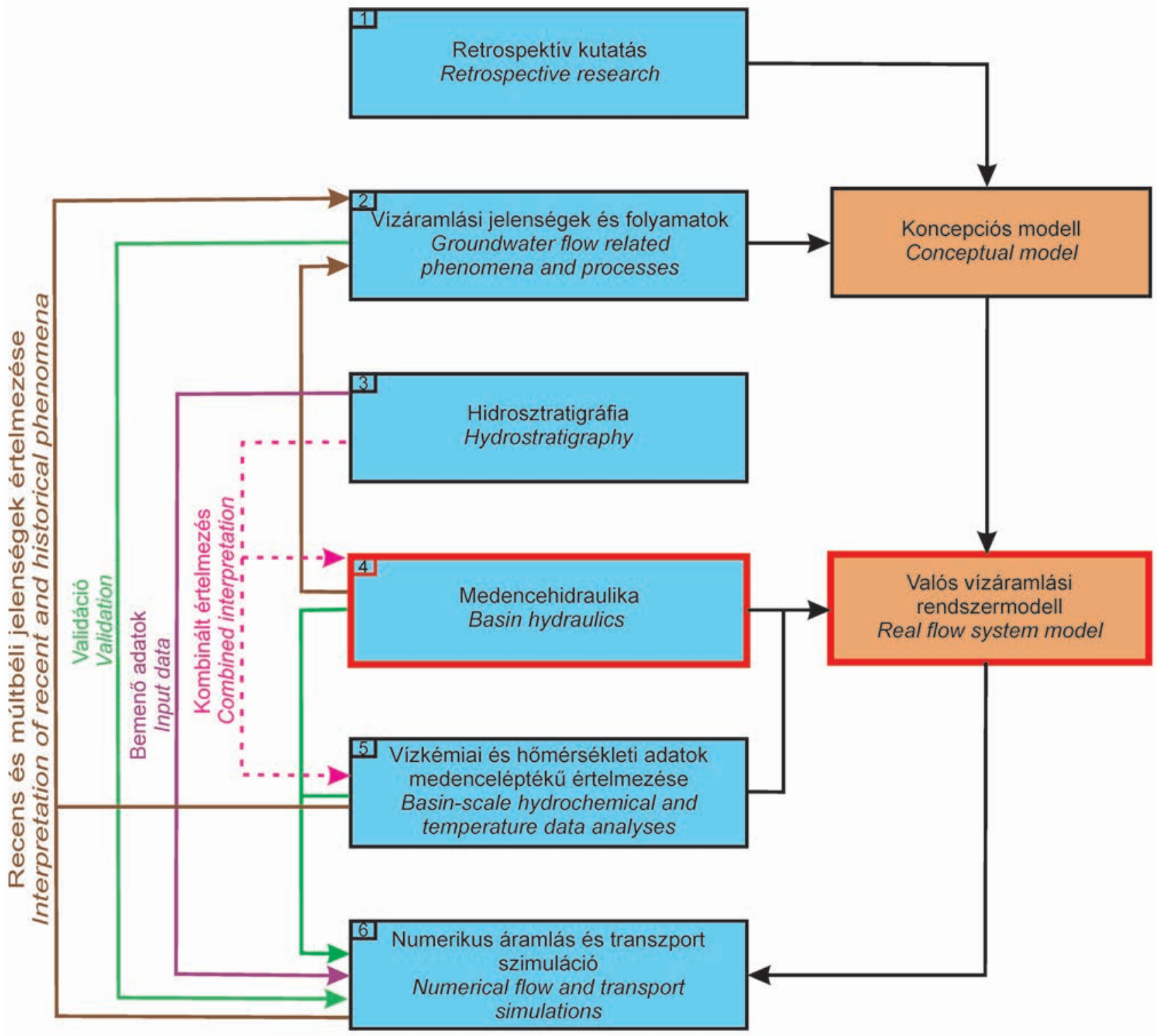

3. ábra. A felszín alatti vízáramlási rendszerek medenceléptékủ vizsgálatának munkafolyamata (MÁDLNÉ SzŐNYI 2019 nyomán módosítva) Figure 3. Workflow for the basin-scale analysis of groundwater flow systems (after MÁDLNÉ SZÖNYI 2019)

sén alapul (3. ábra/2). De magában foglalja a retrospektív vagy történeti dokumentumokon (katonai térképek, levéltári anyagok stb.) alapuló visszatekintő kutatást is (ENGELEN \& KLOOSTERMAN 1996) (3. ábra/l). Utóbbi célja a felszín alatti vizek kvázi „természetes”, emberi befolyástól (pl. víztermelések által okozott depresszió) mentes állapotának rekonstruálása, ezáltal a vízáramlási rendszerek természetes múködési mechanizmusának megismerése.

\section{Hidrosztratigráfia}

A kôzetváz hidrosztratigráfiai jellemzése (3. ábra/3) annak litológiájától függ, így medenceléptékben a litosztratigráfiai egységek egyúttal hidrosztratigráfiai egységként is kezelhetők. A tagolás során a cél a kőzetváz vízvezetô és vízfogó képződményeinek elkülönítése (MAXEY 1964), e- zért medenceléptékben a hasonló hidraulikai viselkedésú (hidraulikus vezetőképességú és permeabilitású) képződményeket összevonjuk (TóTH 1978). Fontos megjegyezni, hogy a vízkémiai és hőmérsékleti jellemzők nem tartoznak a hidrosztratigráfiai értékelésbe a definíció értelmében. Szintén fontos kiemelni, hogy a hidrosztratigráfia közvetlenül nem része a hidraulikai adatfeldolgozáson nyugvó elemzésnek (3. ábra/4). Azonban a 3. ábra értelmében segítséget nyújt a ,valós vízáramlási rendszermodell” felállításához. A hidrosztratigráfia ugyanis genetikusan befolyásolja a folyadékpotenciál eloszlását (TóTH 2009a), mivel a folyadékpotenciál térben észlelhetô anomáliák, rendszerint földtani heterogenitások (azaz jelentősebb permeabilitásváltozások, pl. záró vetók) jelenlétére vezethetôk vissza (pl. RosTRON \& Tóth 1996; AlMÁSI 2001; TÓTH 2003, 2009a; CZAUNER \& MÁDL-SzŐNYI 2011, 2013; MÁDLnÉ SzŐNYI 2019a). Ezek 
vizsgálata céljából a hidrosztratigráfiai értelmezést úgy kombináljuk a medencehidraulikai módszerekkel, hogy a profilokon, térképeken és szelvényeken a hidraulikai adatok mellett a hidrosztratigráfiai felépítést is feltüntetjük. Emiatt az adatfeldolgozáson nyugvó medencehidraulikai munkák esetén - figyelembe véve az elérhető hidraulikai adatmenynyiséget és adateloszlást - a nagyobb léptékú heterogenitásokat hangsúlyozó litosztratigráfiai tagolás és regionális szerkezeti helyzet többnyire elegendő alapot nyújt a hidraulikai és a kapcsolódó értelmezésekhez. Ugyanakkor a medenceléptékből kiinduló és egyre részletesebb numerikus modellezések a hidrosztratigráfiai feldolgozás finomítását igénylik (MÁDL-SzŐNYI \& TóTH 2009, BALOGH 2016, KAPILLER 2016). Ezekben ugyanis a hidraulikus vezetőképesség-értékek már bemenő paraméterként szolgálnak az áramlási irányok és intenzitások meghatározásához.

\section{Medencehidraulika}

A hidraulikai kútadatok medenceléptékú, azaz medencehidraulikai elemzése (3. ábra/4) során a teljes vizsgált területet a felszíntől a medencealjzatig (beleértve a víztartókat és vízfogókat is) egységesen kezeljük és értékeljük. Itt a cél a stacioner áramlási tér feltérképezése, ugyanis az áramképek ennek megjelenítésére alkalmasak. Ezért a vízkutak és szénhidrogén-kutató fúrások eredeti kútdokumentációban rögzített, létesítéskor mért vízszint, illetve pórusnyomás adatait elemezzük, mivel ezek tükrözik leginkább a „kvázi természetes", azaz fluidumtermelés elôtti állapotot. Magyarországon az 1970-80-as évektől kezdődő intenzív vízkivétel előtti állapot tekinthető „,kvázi természetesnek” a vízszintek szempontjából. Fontos megjegyezni, hogy mivel ezek a kútadatok különbözô időpontokból származnak, így a stacioner áramlási tér értelmezhetôségéhez feltételezzük, hogy a hidraulikus emelkedési magasság változásainak különbségei $(\Delta \mathrm{h})$ az adott léptékben vizsgálva beleférnek a medenceléptékú probléma hibahatárába. A körültekintő adatszúrést követô hidraulikai számításokhoz (hidraulikus emelkedési magasságok átszámítása pórusnyomás-adatokká és fordítva) meg kell határozni egy átlagos vízsûrúségértéket, mivel a különböző pontokra meghatározott folyadékpotenciál-értékek csak azonos súrúséggel számítva hasonlíthatóak össze (HuBberT 1940, LuSCZYNSKI 1961). Számításaink és regionális kutatási tapasztalataink szerint az 1000 $\mathrm{kg} / \mathrm{m}^{3}$ vízsûrúség alkalmazható a Pannon-medencében. CZAUNER (2012) számításai rámutattak, hogy a magas geotermikus gradiens $\left(50{ }^{\circ} \mathrm{C} / \mathrm{km}\right)$ és a relatíve alacsony (max. $40 \mathrm{~g} / \mathrm{l}$ ) oldottanyag-tartalom hatása nagyjából kiegyenlíti egymást. A kimutatható eltérések a medencehidraulikai feldolgozás szempontjából elhanyagolhatóak (CZAUNER \& MÁdL-SzŐNYi 2013, ERHARDT et al. 2017).

A hidraulikai adatok medenceléptékú megjelenítésének és elemzésének módjai közül három tekinthető alapvetőnek. Ezek a nyomás vs. eleváció profilok [p(z)], tomografikus potenciál térképek $[\mathrm{h}(\mathrm{x}, \mathrm{y})]$, és hidraulikus keresztszelvények $[\mathrm{h}(\mathrm{s}, \mathrm{z})]$. A p $\mathrm{z}$ ) profilokon a nyomásrezsim (közel hidrosztatikus, túlnyomásos vagy alulnyomásos) és az adatpon- tokra illeszthető vertikális nyomásgradiensek $(\gamma)$ értékelhetôk az egyensúlyi, hidrosztatikus értékhez képest. Utóbbi határozza meg a hajtóerô vertikális komponensének irányát: a szuperhidrosztatikus vertikális nyomásgradiens feláramlást, a szubhidrosztatikus leáramlást jelez, míg a közel hidrosztatikus érték a vertikális komponens (és nem a hajtóerő, avagy áramlás) hiányára utal. Ezen túl a nyomásrezsim és a vertikális nyomásgradiens mélységgel történő változásainak mértékéből és jellegéből következtetni lehet a kőzetváz heterogenitásainak hidraulikai szerepére is (CZAUNER \& MÁDL-SZŐNYI 2013, ERHARDT et al. 2017, MÁDLNÉ SzŐNYI 2019a; CsONDOR et al. 2020). Ezért érdemes a profilokon a hidrosztratigráfiai felépítést is jelölni.

A víztartóléptékben készülő „,hagyományos” potenciometrikus térkép definíció szerint egy horizontális és fedett víztartóra szerkeszthetô, ez a kritérium azonban ritkán teljesül a valóságban (dőlő rétegek, szerkezeti tagoltság miatt), ami igaz a Pannon-medencére is. Ezzel szemben a medencehidraulikai megközelítés szerint a tomografikus potenciál térkép egy adott elevációtartományban mért hidraulikus emelkedési magasság értékeinek (vízszintes, X-Y síkban történő) kontúrozásával állítható elő (ALMÁsı 2001). A tomografikus térképeket egymás alatti eleváció intervallumokra (a kutak szúrőközép-értékei mint mérési pontok eleváció szerinti eloszlása alapján) szerkesztjük, és míg az egyes térképeken a hajtóerő horizontális komponensét lehet meghatározni, addig az egymás alatt következő térképek összehasonlításával a vertikális áramlási komponensekre lehet következtetni. (A hajtóerô-vektorokat az egyszerúség kedvéért áramlási irányként jelöljük.) A módszer másik előnye, hogy indirekt módon lehet következtetni a szerkezetek és vízfogó képződmények hidraulikai viselkedésére az általuk okozott folyadékpotenciál- anomáliák alapján. Ezért érdemes a tomografikus potenciál térképekével azonos eleváció intervallumokra hidrosztratigráfiai térképeket (szerkezeti elemekkel kiegészítve) is készíteni (MÁDL-SzŐNYI et al. 2019). A függóleges és lehetőleg a hidraulikus gradiens irányának megfelelő síkban szerkesztett hidraulikus keresztszelvényeken a szelvény síkjába eső vertikális és horizontális hajtóerô komponensek értelmezhetők, míg az azonos nyomvonalon szerkesztett hidrosztratigráfiai és a szerkezeteket is bemutató szelvények nagyban segítik az értékelést.

\section{Vizkémiai és hômérsékleti adatok medenceléptékü értelmezése}

A medencehidraulikai értelmezést érdemes a kutakból származó vízkémiai és hőmérsékletadatok értékelésével is kiegészíteni (3. ábra/5), mivel ezen paraméterek eloszlását a felszín alatti vízáramlások, mint földtani hatótényezők, alapvetően befolyásolják. Annak érdekében, hogy az elemzések összevethetőek legyenek a hidraulikai értelmezéssel, lehetôleg itt is létesítéskori adatokat használunk, és ugyanazon adatfeldolgozási módszereket alkalmazzuk, mint a hidraulikai adatoknál (elevációprofilok, tomografikus térképek, keresztszelvények), lehetôleg azonos területekre, eleváció intervallumokra és szelvény nyomvonalakra. Ezek 
mellett a „hagyományos” módszerek (Stiff-diagram, STIFF 1951), Piper-diagram (BACK 1966), vízkémiai fáciesek meghatározása stb.) alkalmazása is célravezetô lehet. Fontos azonban megjegyezni, hogy a felszín alatti víz kémiai jellege, izotópos összetétele vagy kora nemcsak a vízáramlási rendszerek jellemzőitől (pl. rezsimjelleg, rendúség) függ, hanem a földtani környezettôl (pl. kőzetösszetétel), az éghajlattól és a keveredési folyamatoktól is. Ezért csupán ezen paraméterek alapján nem lehet a valós „,vízáramlási rendszermodellt" felállítani, legfeljebb koncepciós modell alkotható.

\section{Numerikus áramlás és transzport szimuláció}

A „valós vízáramlási rendszermodell” megalkotása után következhet a felszín alatti vízáramlási tér kvantitatív (numerikus) térbeli szimulációja (3. ábra/6). Ennek célja a felszín alatti vízáramlási rendszerek múködésének, fizikai folyamatainak megértése, ami megalapozza a kvantitatív értékelést. Az ilyen jellegú modellezésekhez koncepciós hátteret, peremfeltételeket és validációs lehetőséget nyújt a „valós vízáramlási rendszermodell”. Ugyanakkor a medencehidraulikai vizsgálatok és eredmények, valamint a medenceléptékú vízáramlási és transzport modellezés együttesen segít számos vízáramláshoz köthető jelenség recens és geológiai időskálán történő értelmezésében (3. ábra). Érdemes még megjegyezni, hogy míg a medencehidraulikai elemzések célja a hajtóerőtér feltérképezése (3. ábra/4), addig az áramlási intenzitások és irányok egzakt értékelése csak a numerikus modellezéssel lehetséges.

\section{Eredmények az ELTE-n}

A következókben a Magyarország területének jelentôs részét lefedő (4. ábra) medenceléptékú kutatásaink öszszegzett eredményeit mutatjuk be. A hangsúlyt nem anynyira a konkrét eredményekre, mint inkább a medencehidraulikai megközelítés szemléltetésére helyezzük. A vázolt témakörökben további részletek a hivatkozott publikációkban olvashatók.

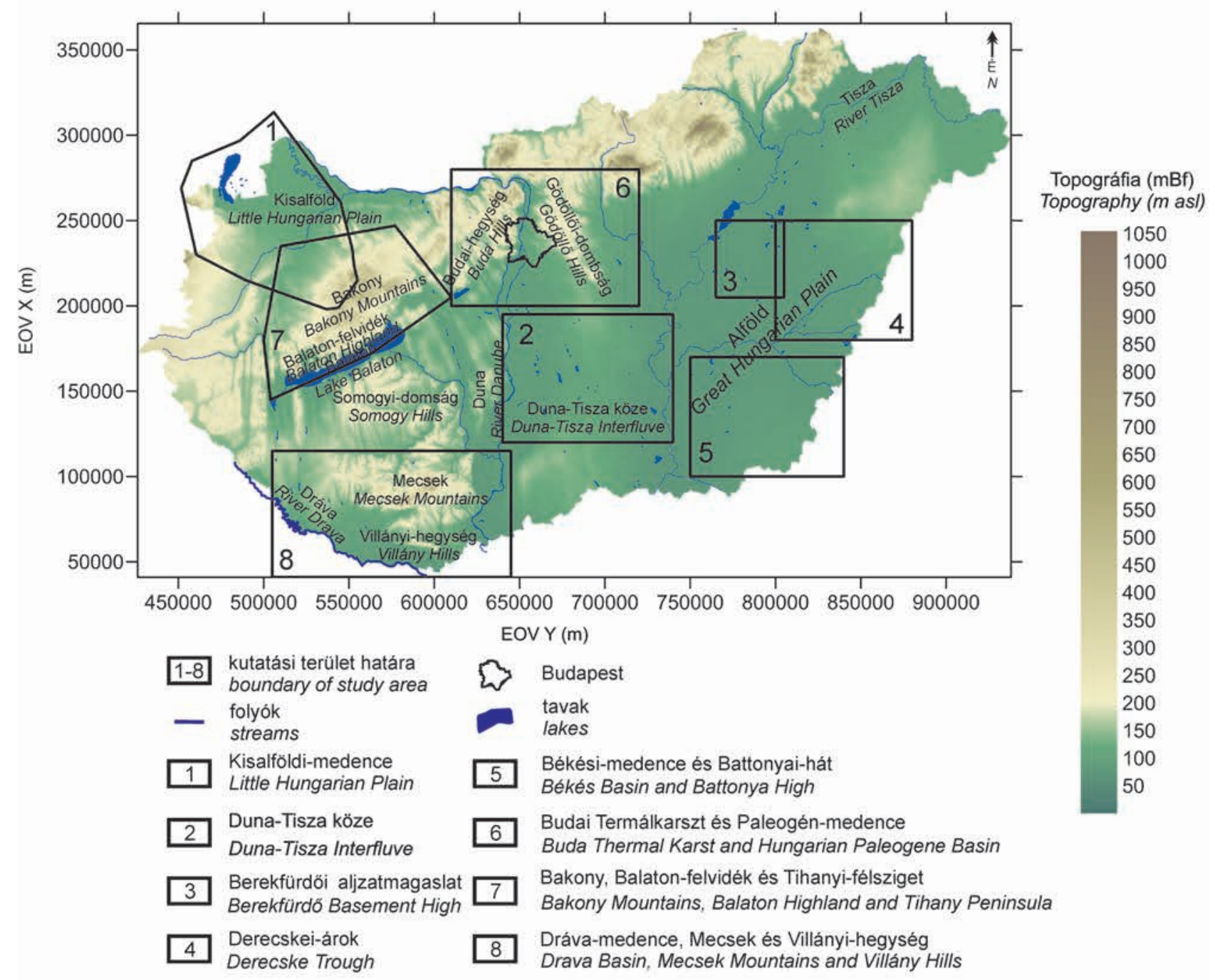

4. ábra. A bemutatott kutatási területek elhelyezkedése Magyarországon

Figure 4. Position of the presented study areas 


\section{Kisalföldi-medence}

Az elsô medenceléptékú hidrogeológiai kutatásokat az OVF (Országos Vízügyi Fớigazgatóság) megbízásából vízbázisvédelmi intézkedések megalapozása céljából - végeztük a Kisalföldi-medence magyarországi részére vonatkozóan (4. ábra) (PETHó et al. 2004). Ennek során igazolást nyert vízkutatási célú kutak hidraulikai adatainak feldolgozásával a Kisalföldi-medence rétegösszleteinek hidraulikus folytonossága és a gravitációs, azaz felszíni topográfia által vezérelt áramrendszerek múködése -1000 mBf (méter a Balti-tenger szintje felett) elevációig. E csapadékból utánpótlódó vízáramlási rendszerek beáramlási területei a medence peremén fekvô dombok és elôtereik, míg ezek irányából a víz a medence belsejében fekvő kiáramlási területek felé áramlik. Azonban a -1000 (-1800) mBf eleváció intervallumban változás tapasztalható, ahol a medence mély, központi részein jelentkeznek a legnagyobb hidraulikus emelkedési magasság értékei. A kimutatott túlnyomás magyarázatával a kutatás nem foglalkozik, de jelentkezési helye és szintje kijelöli a gravitációsan vezérelt vízáramlási rendszerek alsó határát. A feldolgozás egyúttal igazolta a kisalföldi Duna-szakasz mentén a beáramlási (felső Szigetköz) és a kiáramlási területek (alsó Szigetköz) folyó menti megjelenését, ami a folyó és a felszín alatti vizek kapcsolatának (rátápláló, illetve megcsapoló) megváltozását medencehidraulikai feldolgozással bizonyítja. Továbbá rámutatott arra is, hogy erre az eltérô, de permanens hidraulikai kapcsolatra szuperponálódik a Duna vízszintváltozásából adódó tranziens hatás.

\section{Duna-Tisza köze}

Az alföldi részterületek kutatásának ALMÁsI (2001) és TóTH \& ALMÁsI (2001) az Alföldre kiterjedô medencehidraulikai tanulmánya biztosított hátteret. E tanulmányok sorozata szemlélteti, hogy a medencehidraulikai kutatások növekvő léptékben és csökkenő területre végezve a vízáramlási rendszerek szisztematikus és egyre alaposabb megértését teszik lehetôvé. A Duna-Tisza közi tanulmányokat a Duna-völgyben a folyóval közel párhuzamosan megfigyelt magas TDS (összes oldott anyag) tartalom, valamint a vízszintben megmutatkozó kémiai sokszínúség, „foltosság” okainak kutatása inspirálták (KUTI \& KőRÖssY 1989). A kérdés az volt, hogy mi lehet az oldottanyag-tartalom forrása és annak felszínközeli elosztási mechanizmusa. Továbbá ennek összefüggése a felszínközeli szikesedési jelenségekkel (szikes talajok), a tavak, vizenyős területek elhelyezkedésével, jellegével és vizük sótartalmával. A Duna-Tisza köze középsố részére (4. ábra) e kérdések megválaszolása érdekében egy OTKA-kutatás keretében végeztük el a medencehidraulikai elemzést és értelmezést, melyet kiegészítettü-k a kutakból rendelkezésre álló vízkémiai adatok (TDS, $\mathrm{Na}^{+}, \mathrm{K}^{+}, \mathrm{Cl}^{-}$) feldolgozásával. A feltett kérdésekre adott választ és a medenceléptékú kutatás eredményeit a 'Duna-Tisza köze hidrogeológiai típusszelvénye' formájában összegeztük (5. ábra) (MÁDL-SzŐNYI \& TóTH 2009).
Vízáramlási rendszerek és a szikesedési mintázat

Az eredmények megerősítették ALMÁsI (2001) valamint TóTH \& ALMÁsI (2001) felismeréseit az Alföld két különböző, de egymással hidraulikai kapcsolatban álló áramlási tartományát illetően. A gravitációsan (a talajvízszint magasságkülönbségei által) mozgatott, csapadék eredetú vizek felső áramlási tartományát alátámasztja egy túlnyomásos tartomány (ennek vízkészletei nem utánpótlódók). A két eltérő eredetú vízrendszer közötti hidraulikai kapcsolat a neogén Endrődi és Algyői Vízfogókon - mint regionális kiterjedésú vízrekesztôkön - keresztül szerkezeti elemeken és nagy permeabilitású homokkőlencséken keresztül valósul meg. A két tartomány vizeinek oldottanyag tartalma is jelentős különbséget mutat: a gravitációs rendszerben TDS = 420-2 $500 \mathrm{mg} / \mathrm{L}$ (vízkémiai fácies: $\mathrm{Ca}, \mathrm{Mg}\left(\mathrm{HCO}_{3}\right)_{2}$ típus), míg a túlnyomásos rendszer vizeiben a TDS $=10$ 000-38 000 mg/L (vízkémiai fácies: $\mathrm{NaCl}$ típus). A mélységi, nagy sótartalmú vizek feláramlását a teljes vizsgálati területen kimutattuk, melynek lehetséges forrása a preneogén aljzat, míg a preferált áramlási pályát az aljzatból induló és felszínközelbe nyúló vetôrendszerek biztosítják. Erre a regionális feláramlásra szuperponálódik a felszíntől nagyjából 500 m mélységig a meteorikus vizek gravitációs áramlási tartománya, amelynek beáramlási területe a Duna-Tisza közi hátság. Innen a kelet és nyugat felé tartó gravitációs áramlások hierarchikus rendszereket formálnak (lokális, intermedier és regionális), a mélységből feláramló vizeket is eltérítik ezekbe az irányokba, így azok csak keveredve tudnak megcsapolódni a hátsági gravitációs kiáramlási területektől (lokális és intermedier) nyugatra és keletre (5. ábra).

Ez az áramlási mintázat magyarázatul szolgál a hátság menti, nagy kiterjedésû vizenyős területek (gravitációs áramlások lokális és intermedier kiáramlási területei) és az azoktól nyugatra és keletre elhelyezkedő szikes területek (a mélységi eredetú, magas oldottanyag-tartalmú és a meteorikus eredetú regionális áramlási rendszerek kevert vizeivel) elhelyezkedésére. A preneogén medencealjzat a Duna-völgyi szikesek zónájában közelíti meg leginkább a felszínt, továbbá a felszín közelében található, folyóvízi kavicsréteg is segít a mélységi eredetú, magas oldottanyag-tartalmú vizek és a hozzá keveredő gravitációsan mozgatott vizek észak-déli csapás mentén történő felszínre jutásának. Ez magyarázatul szolgál a vízszintben a magas oldottanyag-tartalmú sávok relatíve éles határára a Duna-völgyben. A szikes zóna a Tiszavölgyben inkább foltszerúen, kevéssé élesen jelentkezik hidrosztratigráfiai okok és a preneogén aljzat nagyobb mélysége miatt. Fontos megjegyezni, hogy a megcsapolódó mélységi és a meteorikus eredetú vizek energiája (folyadékpotenciálja) a Nagyalföldi Vízvezetőbe jutva hasonló nagyságrendú. Ennek oka, hogy a mélységi túlnyomás disszipálódik az Endrôdi és Algyői Vízfogókon történő átáramlás során, így a medence eredetú vizeket csak kémiai jellegük különbözteti meg a gravitációs rendszerek meteorikus vizeitől.

A hipotézismodell, az adatfeldolgozás és a „valós vízáramlási rendszermodell” kialakítását, valamint a kapcsolható hidrológiai, vegetációs és szikesedési jelenségek meden- 

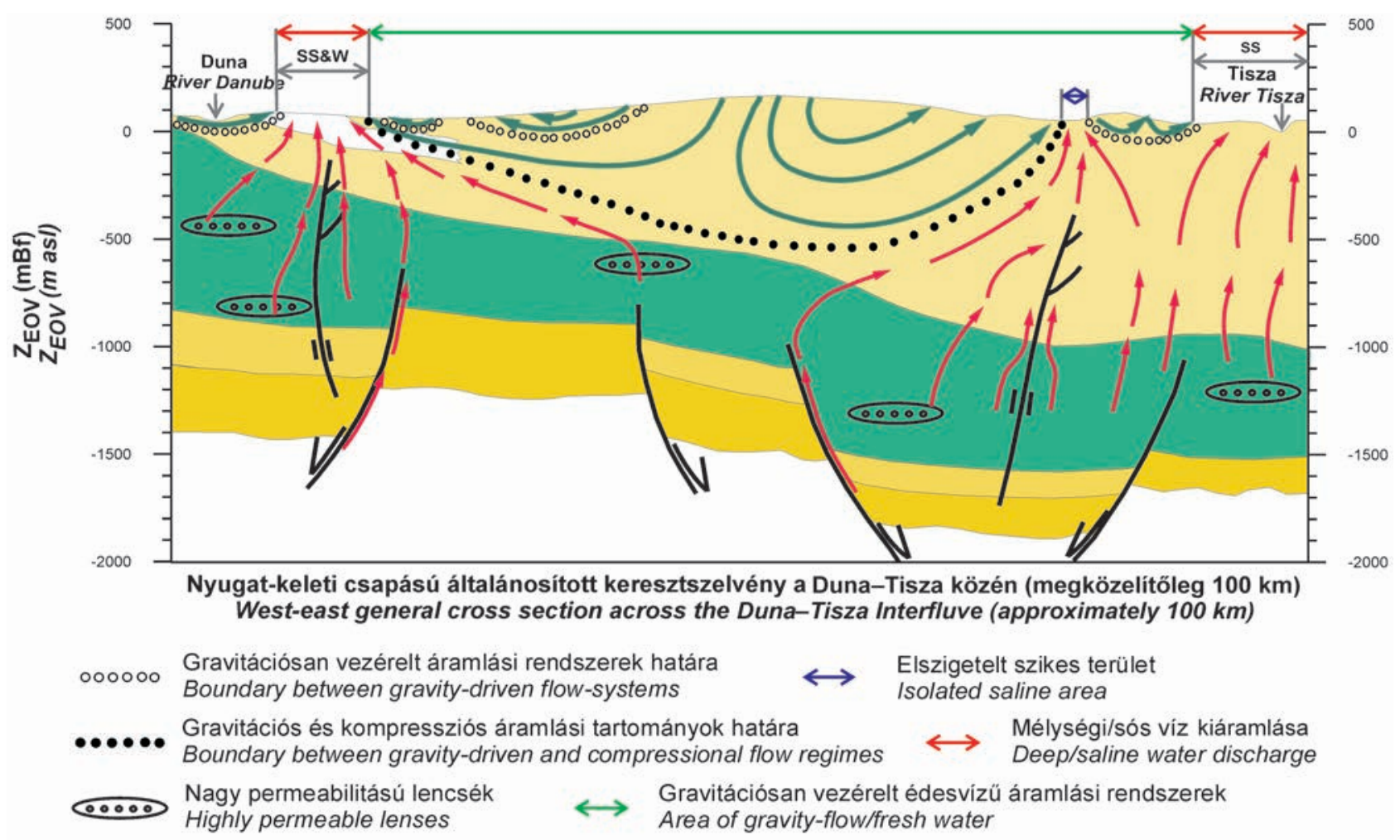

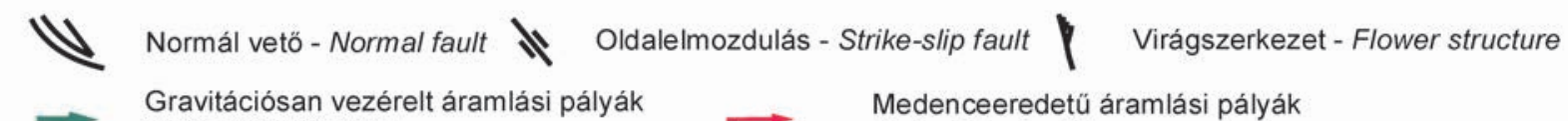

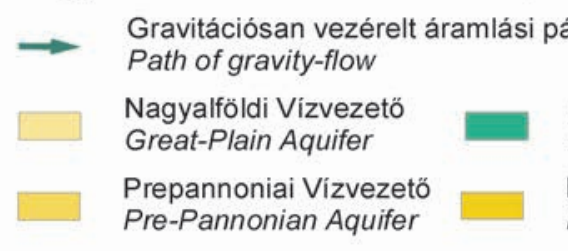

SS\&W: szikes talajok és vizes élöhelyek - saline soils and wetlands
Algyöi Vizfogó, Szolnoki Vízvezetö, Endrödi Vizfogó összevonva summing up of Algyő Aquitard, Szolnok Aquifer, Endröd Aquitard

Preneogén aljzat Pre-Neogene Basement

Kavicsos Vizvezető $\left(\mathrm{AF}_{\mathrm{G}}\right)$ Gravel Aquifer $\left(A F_{C}\right)$

5. ábra. A 'Duna-Tisza köze hidrogeológiai típus szelvénye' (MÁDL-SzŐNYI \& TóTH 2009)

Figure 5. The Duna-Tisza Interfluve Hydrogeological Type Section (MÁDL-SZÖNYI \& TóTH 2009)

celéptékú feldolgozását követôen készült numerikus modellezés (COMSOL Multiphysics) alátámasztotta a medencehidraulikai értelmezés során feltárt hajtóerőteret és a módszertan létjogosultságát. Továbbá a hőtranszport-modellezés kimutatta az advektív hôszállítás szerepét is a területen (BALOGH et al. 2017a,b).

A Duna-Tisza közi kutatások alapkutatási jelentőségükön túl felhívták a figyelmet a Víz Keretirányelv végrehajtása kapcsán a felszíni és felszín alatti víztestek lehatárolása során felmerülő kérdésekre (PADISÁK et al. 2006). Az eredményeik felhasználhatók a Duna-Tisza közi vízellátási problémák kezelése, a mezőgazdasági területhasználat megtervezése, szikes talajok javítása, a lápok és szikes tavak védelme során.

Az Ágasegyházi-, Kolon- és Kelemenszék-tó hidraulikai viszonyai és annak következményei

A regionális elemzés mellett lokális léptékú kutatások is zajlottak a Duna-Tisza közén három tó és a felszín alatti vizek kapcsolatának feltárása céljából. Itt is a kvázi természe- tes állapotot reprezentáló retrospektív kutatásokból indultunk ki. A megközelítőleg azonos kelet-nyugati vonalba és egymástól nagyjából 11-15 km-re esô Ágasegyházi-, Kolon- és Kelemenszék-tó eltérő hidraulikai viszonyai (beáramlási, átáramlási és kiáramlási hidraulikai helyzet), valamint a kapcsolódó felszíni és felszínközeli jelenségek (talajtípusok, vegetáció) alátámasztják a mélységi feláramlás és a gravitációs áramlási rendszerek medencehidraulikai értelmezés során feltárt mintázatát, és lehetôvé teszik azoknak a tavak környezetében történő értelmezését (ZSEMLE et al. 2002, MÁDLNÉ SZŐNYI et al. 2005). A legnyugatabbra esô Kelemenszék-tó környezetében végzett átfogó kutatások bizonyították, hogy a Kelemenszék egy feláramló felszín alatti vizekkel táplált tó (azaz FAVÖKO vagy felszín alatti víztől függő ökoszisztéma), amely a Duna-völgyi szikesek zónájába tartozó „hidraulikai ablakban” található, ahol a mélységi eredetú, magas oldottanyag-tartalmú feláramlás meteorikus eredetû́ vizekkel keveredve, koncentráltan jut felszínre (MÁDLnÉ SzŐNYI et al. 2005; CZAUNER et al. 2008; SimON et al. 2008, 2011). 


\section{Geotermikuspotenciál-értékelés}

A medencehidraulikai feldolgozás eredményei geotermikuspotenciál-értékelésre is használhatók. Ennek módszertanát a Duna-Tisza közi kutatási eredmények alapján dolgozta ki MÁDL-SzŐNYI \& SIMON (2016). Később az eredményeket MÁDLNÉ SzŐNYI (2019b) a Budai Termálkarsztra is adaptálta. A módszertan a ,természetes geotermikus rendszer" elemeit (hő, megfelelő tározó kőzet, fluidum, DicKSON \& FANELLI 2013) medenceléptékben értékeli, kiegészítve azt a hidraulikai, azaz a víztartó és a vízfogó rétegek között fennálló összefüggések megismerésével. Az 1993. évi XLVIII. törvény a bányászatról jelenleg a 2500 m-es felsô mélységhatárral definiálja a zárt, koncesszió alá esố geotermikus rendszereket (melyekbe a kizárólag energetikai célra használt termálvíz visszasajtolása kötelező). Továbbá elkülöníti a fölötte lévő nyitott tározókat. Ezzel szemben a regionális nyomásrezsimek mért adatokra alapozott (medencehidraulikai) feltárása lehetôséget kínál a geotermikus készletek - mélységtől független - zárt és nyitott jellegének, valamint a visszasajtolás előzetes hidraulikai értékelésére (MÁDL-SzŐNYI \& SIMON 2016, MÁdLNÉ SZŐNYI 2019b). A regionálisan fedetlen gravitációs áramlási tartomány nyitott tározónak tekinthetô és a csapadék utánpótlás mértékében termelhető. Besajtolás szempontjából az át- és kiáramlási területeken kisnyomású besajtolás lehetséges, míg a beáramlási területeken energiabefektetés nélkül üzemeltethető nyelő kút. Ezzel szemben a túlnyomásos tározók esetében nem számolhatunk természetes utánpótlással (a termelés a víz és a kôzetváz rugalmas tulajdonságainak, azaz a fajlagos tározás függvénye), ezért ezek zártnak tekinthetôk és csak (nagynyomású) visszasajtolás mellett termelhetôk. Az alulnyomásos tározók szintén zártnak tekinthetők abból a szempontból, hogy az alulnyomás és az utánpótlás hiánya miatt nem termelhetők, ellenben nyelő kút energiabefektetés nélkül üzemeltethetô. Fontos megjegyezni, hogy az értékelési séma nemcsak a geotermikus készletekre, hanem általában a fluidumkészletek (felszín alatti víz, szénhidrogén) termelhetőségére és visszasajtolási lehetőségeire (víz, $\mathrm{CO}_{2}$-elhelyezés) is vonatkoztatható.

\section{Berekfürdói aljzatmagaslat, Derecskei-árok, Békési-medence, Battonyai-hát}

A medencehidraulikai megközelítés a szénhidrogénföldtani kutatásokban is hasznos, a gyakorlatban rutinszerúen nem használt megközelítéssel szolgál. A K- és DK-Alföldön a MOL Nyrt. támogatása mellett végzett medencehidraulikai kutatásaink a vetôk és alacsony permeabilitású képződmények - különösen az Algyői Vízfogó - felszín alatti folyadék áramlási rendszerekben és szénhidrogéncsapdázódásban betöltött szerepére összpontosított.

\section{Szerkezeti elemek lokális hidraulikai szerepe}

Ennek a kutatásnak előfutára volt egy jóval kisebb terület lokális vizsgálata, ahol a vetők hidraulikai szerepének tisztázása volt a cél a preneogén aljzatmagaslat fölötti termálvíz (Berekfürdő) és szénhidrogén (Kunmadarasi földgázmező) előfordulás létrejöttében (4. ábra). Az elvégzett szeizmikus, medencehidraulikai és kapcsolódó vízkémiai elemzések kombinált értelmezése feltárta az aljzatmagaslatot határoló oldalelmozdulási zónák irányonként változó hidraulikai szerepét és hozzájárulását a gázfelhalmozódáshoz, valamint a vetôkereszteződésben a „Pávai-Vajna-féle” egykori termálvízfeltáráshoz (CZAUNER et al. 2008, CZAUNER \& MÁDlNÉ SZŐNYI 2008, CZAUner \& MÁDL-SzŐNYI 2011).

Szerkezeti elemek és kis permeabilitású képződmények regionális hidraulikai szerepe

A Derecskei-árok, Békési-medence és Battonyai-hát területén (4. ábra) a vetôrendszereknek és az alacsony permeabilitású képződményeknek a mélységi túlnyomás lecsengésében (disszipálódásában) játszott regionális hidraulikai szerepét elemeztük, különös tekintettel a szénhidrogén csapdázódás feltételeire (CZAUNER \& MÁDL-SZŐNYI 2013). A víz és szénhidrogén kutak adatainak bevonásával végzett medencehidraulikai és olajhidrogeológiai értelmezés, valamint a kapcsolódó vízkémiai és hőmérsékleti adatfeldolgozás eredményeként itt is sikerült azonosítani a gravitációs áramlási tartományt és annak különböző rezsimjellegû területeit. Továbbá kimutattuk az ezt hidraulikusan alátámasztó túlnyomásos rendszert, amelyben a feláramlás dominál. A két tartomány hidraulikai elkülönítése ott volt lehetséges, ahol a túlnyomásos rendszer feláramlása a gravitációs tartomány beáramlási területei alatt azok lefelé irányuló áramlásaival találkozik. Az ilyen összetartó vertikális áramlások zónáit folyadékpotenciál-minimum jellemzi, ami hidraulikus csapdaként szolgálhat a felszín alatti víz által szállított anyagok számára (TóTH 1980). Mivel a kutatás a szénhidrogénekre koncentrált, így azok vertikális migrációjának felsó határaként definiáltuk ezeket a folyadékpotenciál-minimum zónákat a Derecskei-árok északkeleti részén, illetve a Battonyai-hát mentén (6. ábra).

A kutatás a hidrosztratigráfiai egységeket tekintve megerôsítette, hogy a Nagyalföldi Vízvezetô medenceléptékben megközelítôleg hidrosztatikus nyomásállapotú $(\gamma=9,81 \pm$ 0,5 $\mathrm{MPa} / \mathrm{km}$, ezen belül gravitációs fel- és leáramlások múködnek). Ugyanakkor a Prepannóniai és Preneogén Vízvezetôk erôsen túlnyomásosak (a túlnyomás mértéke a 200\%-ot is meghaladhatja). Eközben a vertikális nyomásgradiens csak enyhén szuperhidrosztatikus, ami vízvezetó jellegükre és a laterális áramlás dominanciájára utal. Ezzel szemben a közbeesô Endrődi Vízfogó, Szolnoki Vízvezetô és Algyőii Vízfogó területenként változó nyomásviszonyokat, de jellemzően szuperhidrosztatikus vertikális nyomásgradienseket (akár >20 MPa/km) mutat. Ebből következik, hogy ennek a három egységnek és különösen az Algyői Vízfogónak a szerkezeti és üledékföldtani heterogenitásai határozzák meg a túlnyomás lecsengésének módját a Nagyalföldi Vízvezetố irányába. Mivel e heterogenitások igen gyakran egybeesnek folyadékpotenciál, hőmérsékleti és vízkémiai anomáliákkal, valamint szénhidrogén-felhalmozódásokkal, ezért diagnosztikus összefüggést lehetett kimutatni a jelenségek együttes előfordulása közt. Kapcsolatrendszerükben a geológiai felépítésnek a túlnyomás lecsengésében játszott szerepe bizonyult meghatározónak. Fontos 


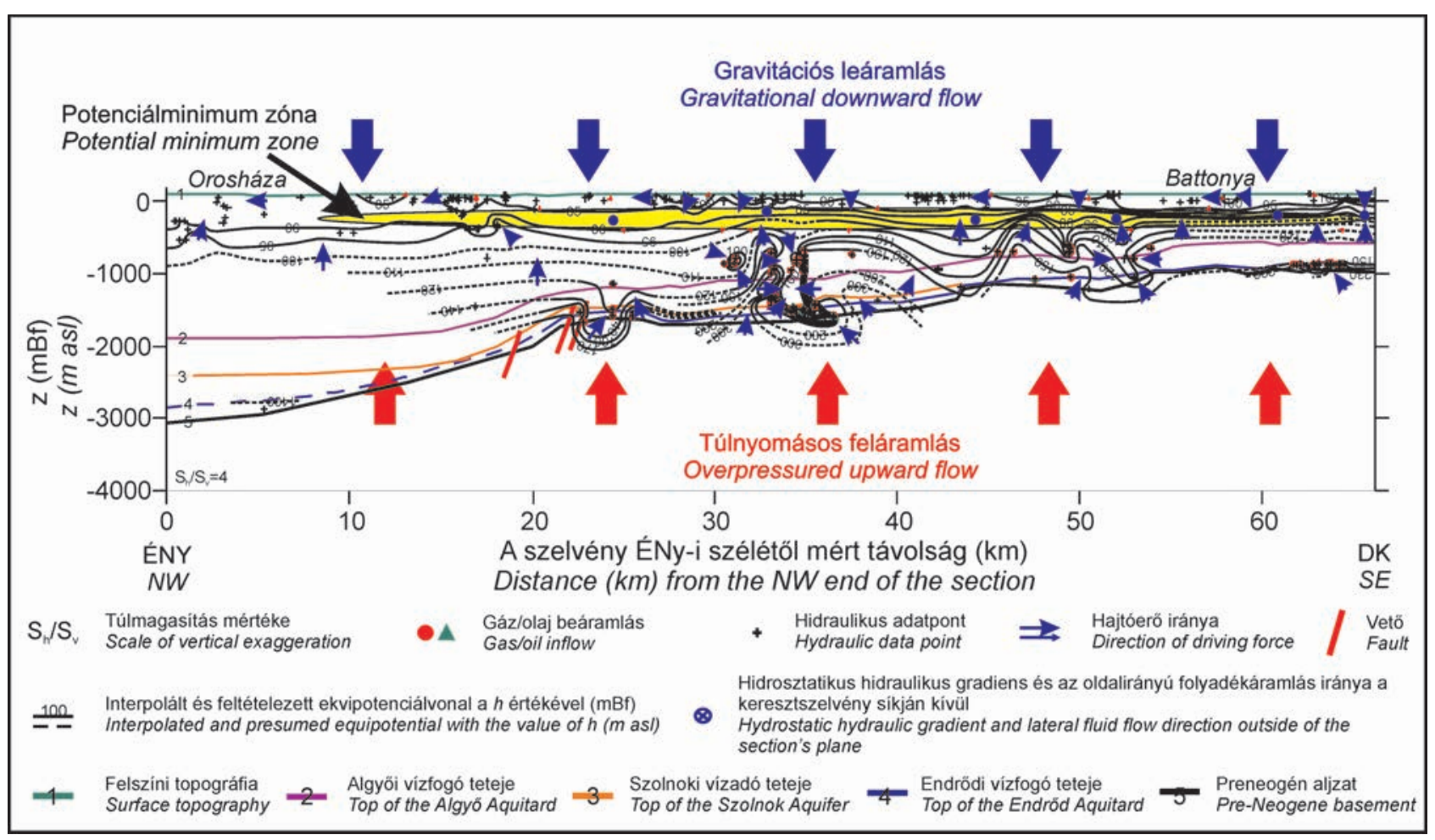

6. ábra. Hidraulikus keresztszelvény a Battonyai-hát mentén a feltárt felszín alatti vízáramlási rendszerekkel és a folyadékpotenciál-minimum (hidraulikai csapda) zónával (CZAUNER \& MÁDL-SZŐNYI 2013)

Figure 6. Hydraulic cross-section along the Battonya High with the interpreted groundwater flow systems and fluid-potential minimum (hydraulic entrapment) zone (CZAUNER \& MÁDL-SZÖNYI 2013)

azonban megjegyezni, hogy ez a kapcsolat kétirányú, ugyanis a folyadékpotenciál-tér is hatással van a kőzetvázra a pórusnyomás változásai révén (TERZAGHI 1923).

Mindezek alapján végül hét régiót különítettünk el a kutatási területeken belül, amelyek geológiai felépítésbeli eltéréseikre visszavezethetôen különbözô túlnyomás-lecsengési módokkal jellemezhetôk. Így például a Derecskei-árok északi peremén az Algyői Vízfogó nagyfokú heterogenitást mutat a sûrú vetôhálózatnak köszönhetően, így a nyomáscsökkenés az egységen keresztül fokozatos, ezért a szénhidrogén-előfordulások az Algyői Vízfogó teljes vastagságintervallumából ismertek. Ezzel szemben az árok déli peremén jóval ritkább a vetôhálózat, így a nyomáscsökkenés lokalizáltan és ugrásszerúen történik az Algyői Vízfogót harántoló vetôk mentén. Eközben a mátrix hatékonyan gátolja a nyomásdisszipációt (azaz a folyadékáramlást), azaz tartja fent a túlnyomást. Ennek eredményeként szénhidrogénmezők itt legsekélyebben az Algyői Vízfogó mélyebb zónáiból ismertek. Azaz ennél magasabb zónákba hidraulikai értelemben gátolt a migráció. A Battonyai-hát területe a hat másik régiótól jelentősen eltérô viszonyokat mutat a preneogén aljzat kiemelt helyzetének, valamint a neogén rétegek kis vastagságának és relatíve nagy permeabilitásának köszönhetően. Ezért túlnyomás itt csak a preneogén aljzatban, nagyjából 2000 m mélységtől jelentkezik. Ugyanakkor szénhidrogén-előfordulások a teljes neogén rétegsorból (és az aljzatból is) ismertek, a hidraulikus csapdázódás már említett zónájánál nagyobb mélységben.

\section{Budai-termálkarszt és Paleogén-medence}

\section{Háttér}

A vastag karbonátos víztartó rendszerek, a bennük zajló vízáramlások és a kapcsolódó hipogén karsztosodási és kiválási folyamatok medencehidraulikai szemléletú kutatásának bevezetésében nemzetközi szinten is kezdeményezó szerepet vállaltunk (GOLDSCHEIDER et al. 2010, MÁDL-SzŐNYI \& TÓTH 2015). Ezért ennek hátterét bővebben ismertetjük. Ebben nagy szerepet játszott, hogy az 1950 és 1990 között zajló intenzív bányászati célú víztelenítés következményei felhívták a figyelmet a Dunántúli-középhegység triász karbonátjaiban fennálló regionális hidraulikus folytonosságra (MÁdLnÉ SzŐNYI 1997, AlFöLdI \& KAPOLYI 2007 stb). E régión belül a Budai-termálkarszt (BTK) természetes ,kutatólaboratóriuma” több mint húsz éve szolgál hidrogeológiai kutatásaink színteréül. Kezdetben a Barlangtani Intézet természetvédelmi, barlang- és forrásvédelmi szempontjai vezéreltek, majd a Shell Ltd. támogatásával a karbonátos rezervoár képződés recens analógiájaként elemeztük a területet. Ezek keretében elvégeztük a retrospektív kutatást, a vízáramláshoz köthetô jelenségek és folyamatok vizsgálatát, a hipotézismodell megalkotását (ERŐss et al. 2008; ERŐss et al. 2012a,b; MÁDL-SzŐNYI \& TóTH 2015; MÁDLSzŐNYI et al. 2019) (7. ábra).

A medencehidraulikai értelmezés több lépésben és léptékben zajlott, melyre egy interdiszciplináris OTKA-kutatás és a MOL Nyrt. támogatásával a Paleogén-medencét is 


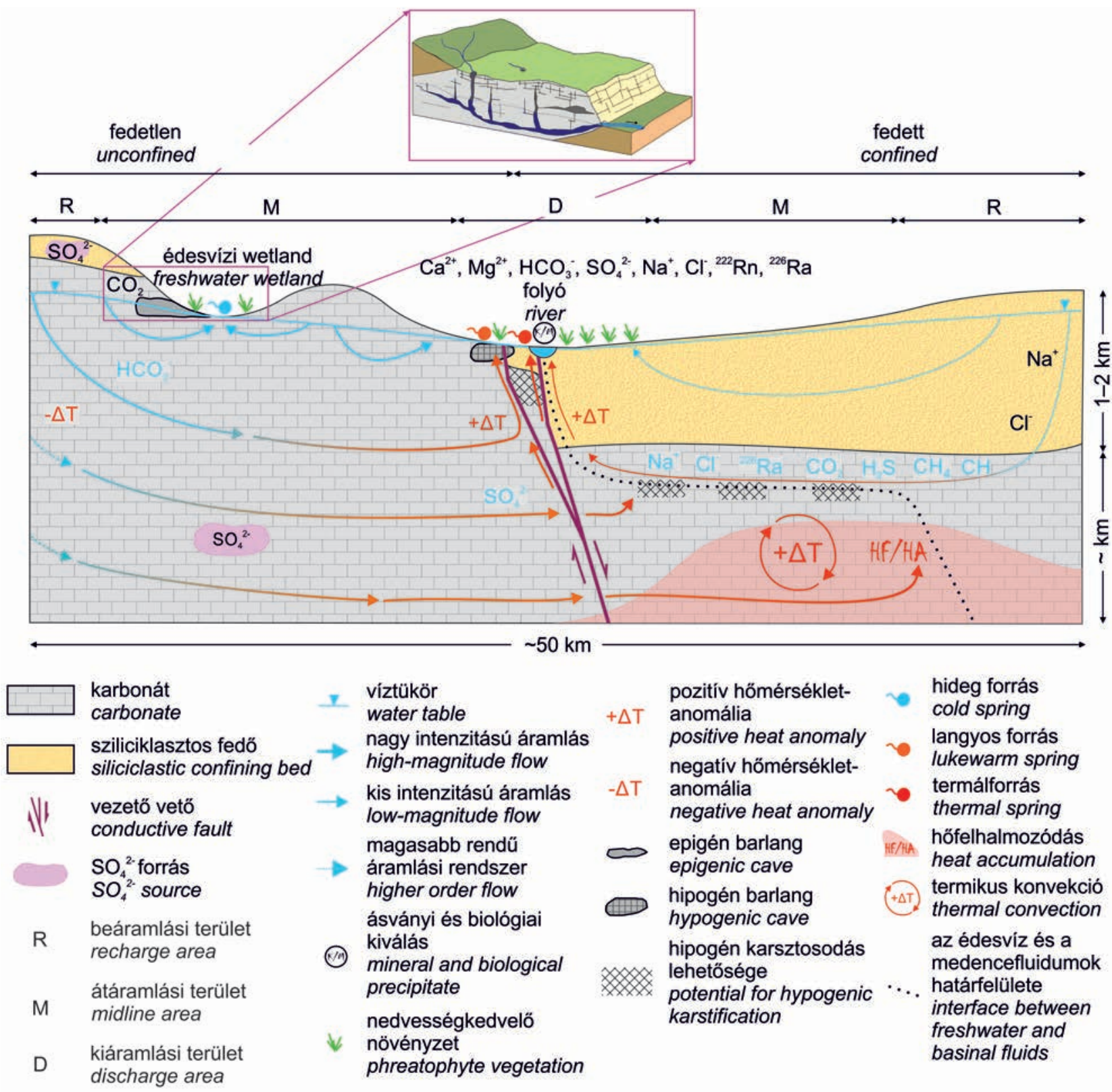

7. ábra. Vastag fedetlen (ill. részben fedett), és csatlakozó sziliciklasztos képződményekkel fedett karbonátos vízadó rendszer vízáramlási hipotézismodellje melyet a medencehidraulikai adatfeldolgozás alátámasztott -, a kapcsolódó jelenségekkel együtt (MÁDLNÉ SZŐNYI 2019a MÁDL-SzŐNYI \& TóTH 2015 után módosítva). A sekély karsztok lokális vízáramlási rendszerekként (GOLDSCHEIDER \& DREW 2014 nyomán) illeszthetők be a medenceléptékủ modellbe

Figure 7. Conceptual groundwater flow model, which was confirmed by the basinhydraulic data analysis, and its consequences of flow-related manifestations for the interface of confined and unconfined carbonates (MÁDLNÉ SZÖNYI 2019a modified after MÁDL-SZÖNYI \& TóTH 2015). The shallow karst aquifer (modified after GOLDSCHEIDER \& DREW 2007) is embedded into the regional flow pattern as a local system

magában foglaló (4. ábra) kutatás teremtett alapot (ERHARDT et al. 2017, MÁDL-SzŐNYI et al. 2019). Ezek eredményeképpen került sor a hidraulikus folytonosság módszertani érvényesítésére és egyben bizonyítására, valamint a „valós vízáramlási rendszermodell”megalkotására (MÁDLNÉ SZÓNYI 2019a). Ezek alapozták meg a területre vonatkozó vízáramlási és transzport szimulációkat (HAVRIL et al. 2016, SZIJÁRTó et al. 2020), valamint a vízáramláshoz köthető jelenségek, elsôdlegesen a megcsapolódási jelenségként értelmezett biogeokémiai kiválások további vizsgálatát (KovÁcs-Bodor et al. 2018, 2019). A BTK-n végzett kuta- tásaink így reprezentálják a medenceléptékú kutatások munkafolyamatának teljes ciklusát (3. ábra). Az alábbiakban ezekből a kutatásokból sokrétúségük folytán csak a medencehidraulikai eredményekre koncentrálunk.

A vastag karbonátos víztartó rendszerek medencehidraulikai sajátosságai

Az eddigiekben bemutatott alföldi és kisalföldi kutatási területekhez képest a BTK és Paleogén-medence esetében jelentős különbség mutatkozik a topográfia, a fejlődéstörténet és a hidrosztratigráfiai felépítés komplexitását tekintve 
is. Egyrészt az eddigi síkvidéki kutatási területekhez képest a domborzat itt változatos, magában foglalja többek között a Budai-hegységet (max. 559 mBf), a Gödöllői-dombságot (max. $344 \mathrm{mBf}$ ) és a Pesti-síkságot (95-120 mBf) is. A másik különbség, hogy míg az eddigi példákban egy medence süllyedéstörténetével, addig itt a süllyedés mellett a hegységek és dombságok kiemelkedésével is számolni kell. Végezetül a hidrosztratigráfiai felépítés is eltérő, hiszen a sziliciklasztos medencékben a pannóniai vízfogók hidraulikai szerepe volt meghatározó, míg itt a kutatás elsődlegesen a pretercier karbonátos képződmények vízáramlási rendszereire irányult. A földtani felépítés változatosságát jelzi, hogy ezek a karbonátok a BTK területén részben fedetlen helyzetben találhatók, míg a Paleogén-medencében - annak pretercier aljzatát képezve - akár 2000 m vastag, uralkodóan sziliciklasztos fedő alatt találhatók. E kutatás során módszertant dolgoztunk ki arra vonatkozóan, hogy az egyedi képződményekre levezetett hidrosztratigráfiai tagolásból a medenceléptékú feldolgozáshoz azok összevonásával csoportokat (Hidrosztratigráfiai Csoport - HCS) vezessünk le (MÁDL-SZÓNYI et al. 2019, GARAMHEGYI et al. 2020). A képződmények közül a pretercier karbonátok alkotta HCS1 Vízvezető (VV) jellemezhető a legnagyobb hidraulikus vezetôképességgel, míg a fedôképződmények közt az oligocén sziliciklasztos (Tardi és Kiscelli Agyag dominálta) HCS3 Vízfogó (VF) képviseli a legalacsonyabb vízvezetô-képességi értékeket. Így ennek a hidraulikai szerepe a leghangsúlyosabb a medenceléptékú vízáramlási rendszerek mintázatában. Ugyanakkor a korábbi példák esetén hangsúlyos pannóniai és fiatalabb képződmények itt egy csoportba (HCS5 Vízvezetô-Vízfogó (VV-VF)) kerültek.

A medencehidraulikai kutatás során a fönti eltérések miatt módszertani fejlesztésekre is szükség volt, mivel az eredetileg sziliciklasztos medencékre lett kidolgozva. Ennek következtében a BTK és Paleogén-medence területén folytatott adatfeldolgozás egyik legfőbb eredménye, hogy bizonyította a medencehidraulikai módszerek alkalmazhatóságát vastag karbonátos víztartó rendszerek környezetében is (ERHARDT et al. 2017, MÁdL-SzŐNYI et al. 2019, MÁdLNÉ SZŐNYI 2019a).

\section{A BTK vízáramlási rendszerei és felszín alatti határa}

A kutatás eredményeként kimutattuk, hogy a gravitációs hajtóerô, azaz a vízszintkülönbségek mozgatják döntően a vizeket -500 mBf elevációs szintig. Meghatároztuk a vízáramlások vertikális komponenseit, melyek az áramlások hierarchizáltságát (lokális/intermedier/regionális áramlások) előidézik, és lehatároltuk a különböző rendú áramlási rendszerek utánpótlódási területeit a Pilis, a Budai-hegység és a Gödöllői-dombság területén (MÁDLNÉ SzŐNYI 2019a). Az ezekhez tartozó megcsapolódási területek kijelölésénél a medencehidraulikai értelmezést a források hierarchikus klaszterezéséből levezetett lokális, intermedier és regionális áramlásokhoz köthető jellegével is kiegészítettük (MÁDLSzŐNYI \& TóTH 2015, MÁDLNÉ SzÓNYI 2019). A BTK fô megcsapolódási területe $0 \mathrm{mBf}$ eleváció szintig Visegrádtól a Duna völgyében húzódik, majd a Csepel-sziget északi csúcsától déli irányban kiszélesedik. A $0 \mathrm{mBf}$ elevációs szint alatt keleti-délkeleti irányú átáramlás figyelhetô meg a Duna alatt (ERHARDT et al. 1017, MÁDL-SzŐNYI et al. 2019). Mindezek alapján javaslatot tettünk a BTK felszín alatti vízgyưjtőjének hidraulikai lehatárolására, ami vízminőségi és vízkészlet gazdálkodási szempontból is meghatározó jelentôségú (MÁdLnÉ SzŐNYi 2019a).

Hidraulikus folytonosság és elkülönülés a BTK és a Paleogén-medence vízáramlási rendszerén belül

A 500 mBf eleváció alatt a domborzat hatása már nem észlelhetô, a folyadékpotenciál-eloszlás hidrosztatikushoz közeli viszonyokat tükröz, azaz az átáramlás dominanciáját. Mindez egybevág azzal, hogy az áramlási rendszer elsődlegesen utánpótlásvezérelt (HAITJEMA \& MitcheLL-BRUKER 2005, HAVRIL et al. 2016). A víztükördomborzat hatásának kisebb mértékú érvényesülése a karbonátos víztartóknak a sziliciklasztos kőzetekkel összevetve nagyobb hidraulikus diffuzivitásával (a pórusnyomás-változás terjedését leíró formációtulajdonság) magyarázható, ami a hidraulikus kapcsolatok erősödését és így a potenciálkülönbségek kiegyenlítődését okozza (MÁDL-SzŐNYI \& TóTH 2015). Ebből adódóan a vízszintdomborzat kevésbé követi a térfelszín lokális változékonyságát, sokkal inkább regionális lejtése meghatározó, míg az áramlási rendszerek kevésbé hierarchizáltak, és az áramtérben az átáramlás domináns. A nagyobb hidraulikus diffuzivitás további következménye, hogy mivel a hidraulikai kapcsolat vagy összefüggés (azaz folytonosság) a karbonátos víztartókban jóval hatékonyabb, így ezen a folytonos téren belül a torlasztó vetôk és a regionális vízfogó képződmények (HCS3 VF) hatékony hidraulikai elkülönülést tudnak okozni. Ezt az ekvipotenciálok besûrûsödése, valamint a vízkémiai és hômérsékleti különbségek is jelzik (MÁDL-SzŐNYI \& TóTH 2015, MÁDL-SzŐNYI et al. 2019; MÁdLnÉ SzŐNYI 2019a). A legmarkánsabb vízfogó, a HCS3 VF regionális hidraulikai szerepét tekintve eltérô hatású a vastagsága függvényében. A budai oldalon, ahol kisebb vastagságú a vízfogó (200-400m) vagy hiányzik, a hidraulikai kapcsolat a fekü (HCS1-2) víztartóval intenzívebb, ami a (felső sziliciklasztos és karbonátos HCS4-5) víztartók potenciálértékeinek regionális kiegyenlítődésében jelentkezik. Ahol azonban nagy vastagságban van jelen a vízfogó, ott nagyobb potenciálkülönbség tud fennmaradni a fedő és fekü vízadók közt, így például a Gödöllői-dombság területén (MÁDLNÉ SzŐNYI 2019a).

\section{Potenciálanomáliák az áramlási térben}

A 1000 mBf eleváció alatti tartományban továbbra is az átáramlás dominál, mégis jelentős változások figyelhetôk meg a potenciáleloszlásban. Az átáramlás oka, a beszivárgásvezérelt rendszerben kialakult regionális vízszintkülönbségekből adódik. A potenciáleloszlásban tapasztalt anomáliák az eddigi alföldi példák mélységi túlnyomásával szemben a Paleogén-medence fedett pretercier karbonátjaiban és paleogén vízvezetőiben (HCS1-2 VV) jellemzően inkább alulnyomásként jelentkeznek (1-2 MPa nyomásdefi- 
cit) (8. ábra) (MÁdL-SzŐNYI et al. 2015, MÁDL-SZŐNYI et al. 2019). Ez egyrészt leáramlást generál a fedőből a fekü HCS1-2 víztartókba, amit ebben a mélységben a vízszintkülönbségek már nem indokolnak (MÁDLNÉ SZŐNYI 2019a). Másrészt a sekélyebb szintekben a BTK kiemelt területei felől érkező, Pest alatt megforduló és a Duna felé irányuló horizontális (át)áramlási komponens a mélyebb szintekben a BTK felől a Paleogén-medence felé irányul az ott jelentkezô nyomásdeficit miatt. Az oligocén HCS3 Vízfogón keresztüli leszivárgás további következménye, illetve indirekt bizonyítéka a hidrosztratigráfiai csoporton belül ismert anyakőzetekből (Tardi Agyag) a szénhidrogén lefelé történő migrációja és a feküképződményekben való felhalmozódása. Az alulnyomás előidézésében feltehetően több jelenség, ill. folyamat együttes hatása játszhat szerepet (MÁDL-SzŐNYI et al. 2015, MÁDL-SzŐNYI et al. 2019, MÁDLNÉ SZŐNYI 2019a). Így a HCS3 Vízfogó (200-1000 m vastagságú) jelenléte geológiai idôskálán vertikális, míg a Tóalmás-vonal és a Szada-vetố hidraulikai zárása kelet-délkeleti irányban laterális utánpótlódási hiányt okozhat a HCS1-2 víztartókban. Szintén szerepe lehet az alulnyomás kialakulásában a Gödöllői-dombság 4 millió éve megkezdődött kiemelkedésének és az ezzel együtt járó eróziónak, ami megbontva a pórusnyomás és a hatékony feszültség egyensúlyát eróziós dekompakciót idézhetett elő (MÁDL-SzŐNYI et al. 2015). De elméleti modellezéseinkben kimutattuk, hogy a gravitációs hajtóerô és kényszerkonvekció mellett jelen lévő hőmérséklet-különbség és a sótartalom-különbség (ld. később) hatására fellépő szabad konvekció is felelőssé tehetô hasonló mértékú potenciálanomáliák kialakításáért az áramlási térben (GALSA et al. 2019, SzIJÁRTó et al. 2019a).

\section{Hőmérsékleti és vízkémiai jellemzők medencehidraulikai értékelése}

A medencehidraulikai értelmezést a hőmérsékleti és vízkémiai (TDS, $\mathrm{Cl}^{-}$) adatfeldolgozás eredményei is megerősítették. Az oldottanyag-tartalom eloszlásában is tükröződik a domborzat, a hidrosztratigráfia, a szerkezetek és ebből következően a hidraulikai kapcsolatok áramlási képre gyakorolt hatása (MÁDL-SZŐNYI et al. 2019, MÁDLNÉ SzŐNYI 2019a). Így például a Tóalmás-vonaltól DK-re a fedett karbonátos víztartókban drasztikusan megnövekedett oldottanyag-tartalom alátámasztja a szerkezeti vonal hidraulikai vízrekesztő szerepét. A BTK szempontjából kiemelkedő jelentôségú eredmény, hogy sikerült térben és a hidraulikához köthetően elkülöníteni a „karsztvíz” és a korábban feltételezett ,,medencefluidum” (ALFöLDI 1979) jelenlétét a rendszerben (ERőss et al. 2011, 2012a, b; Poros et al. 2010, 2012; MÁDL-SzŐNYI \& Tóth 2015; MÁDLnÉ SzŐNYI et al. 2018). Továbbá a medencehidraulikai feldolgozás alapján a karsztvízkomponens mellett egy „hidrotermális” komponens jelenlétét is ki tudtuk mutatni (MÁDLnÉ SzŐNYI et al. 2018,MÁdLnÉ SZŐNYi 2019a).

A budai oldalon a (1) karsztkomponens (TDS < 1000 $\left.\mathrm{mg} / \mathrm{l} ; \mathrm{Cl}^{-}<30 \mathrm{mg} / \mathrm{l}\right)$ meteorikus eredetú, és a Budapesttől nyugatra fekvő és hidraulikailag is kimutatott utánpótlódási területeken jut a felszín alá, majd helyi és intermedier áram- lások révén jut a felszínre a Duna vonalában. A (2) medencekomponens a karbonátos víztartót fedő oligocén (HCS3 VF) és fôként az alsó- és középsô-miocén (HCS4 VV-VF) képződmények tengeri eredetû, átalakult (NaCl-os) pórusfolyadékából származtatható. Ez a budai oldalon az utánpótlódási területek leáramlásai, a Paleogén-medencében pedig az alulnyomás generálta leáramlás révén jut a karbonátos víztartóba (HCS1 VV). A (3) hidrotermális komponens a budai oldal regionális beszivárgási területein jut a felszín alá, eredetét tekintve ez is meteorikus karsztvíz, behatolása a mélység irányában, a Duna és a pesti oldal alatt „édesvíz” front formájában kelet felé nyomozható. A hosszú felszín alatti tartózkodási ideje és a víz-kőzet kölcsönhatás miatt átalakuláson esik át, majd a megcsapolódás során medencekomponens is hozzákeveredik.

\section{Aszimmetrikus áramlási kép}

A vízáramlási pályák aszimmetrikus jellege, azaz a nyugatról érkező Duna alatti átáramlás, majd a nyugat felé történố visszatérülés a BTK-ra vonatkozó korábbi - tisztán hipotézisen alapuló - koncepcionális modellek mindegyikében megjelent (SCHAFARZIK 1928, VENDEL \& KisháZI 1964, KovÁcs \& MÜller 1980, AlFöldi 1981 stb.). E kérdést ismét felvetve a jelenséget medencehidraulikai feldolgozással és medenceléptékú numerikus modellezéssel (ekvivalens porózus közeg megközelítéssel) is sikerült kimutatnunk (MÁdL-SzŐNYI \& TóTH 2015). E tanulmányban tisztáztuk a jelenség hidrosztratigráfiai okát, melynek következménye a budai és pesti oldal közti hajtóerô és beszivárgás különbség (7. ábra). Az előzőekben hivatkozott koncepciós modellek a sziliciklasztos fedőrétegeket ab ovo impermeábilisként kezelték, ezért nem számoltak medencefluidum hozzájárulásával sem. Ebben az értelemben mind a medencehidraulikai feldolgozás, mind pedig a medenceléptékú modellezés új eredményeket hozott.

Végül a mért adatok medencehidraulikai és kapcsolódó vízkémiai értelmezése az aszimmetrikus áramlási képet a budapesti központi megcsapolódási rendszer (Rózsadomb előtere) hidrotermális vízkomponensére vonatkozóan igazolta (MÁdLNÉ SzŐNYI et al. 2018, MÁDLNÉ SZŐNYI 2019a). Az aszimmetrikus áramkép kérdését azóta általánosságban is kiterjesztettük, és elemeztük kialakulását különböző medencealakulatok és hidrosztratigráfiai adottságok mellett (TótH et al. 2020).

\section{Következmények}

Módszertani szempontból a medenceléptékú adatfeldolgozás és numerikus modellezés közös eredménye tehát, hogy keretbe helyezte a BTK kútjaiban és forrásaiban felszínre jutó vizek ismert különbözőségét (ld. 3. ábra, ,recens jelenségek értelmezése"). Erre építve tágabb összefüggésben tudtuk értelmezni nemcsak a Budapestnél megcsapolódó vizek fentiekben leírt lehetséges eredetét (az utánpótlódási területeket és áramlási rendszereket figyelembe véve), valamint azok hőmérsékleti, kémiai és izotópösszetételében megnyilvánuló különbözőségét, hanem a mindezek következményeként értelmezhető biogeokémiai és ásványkiválásokat, valamint poro- 


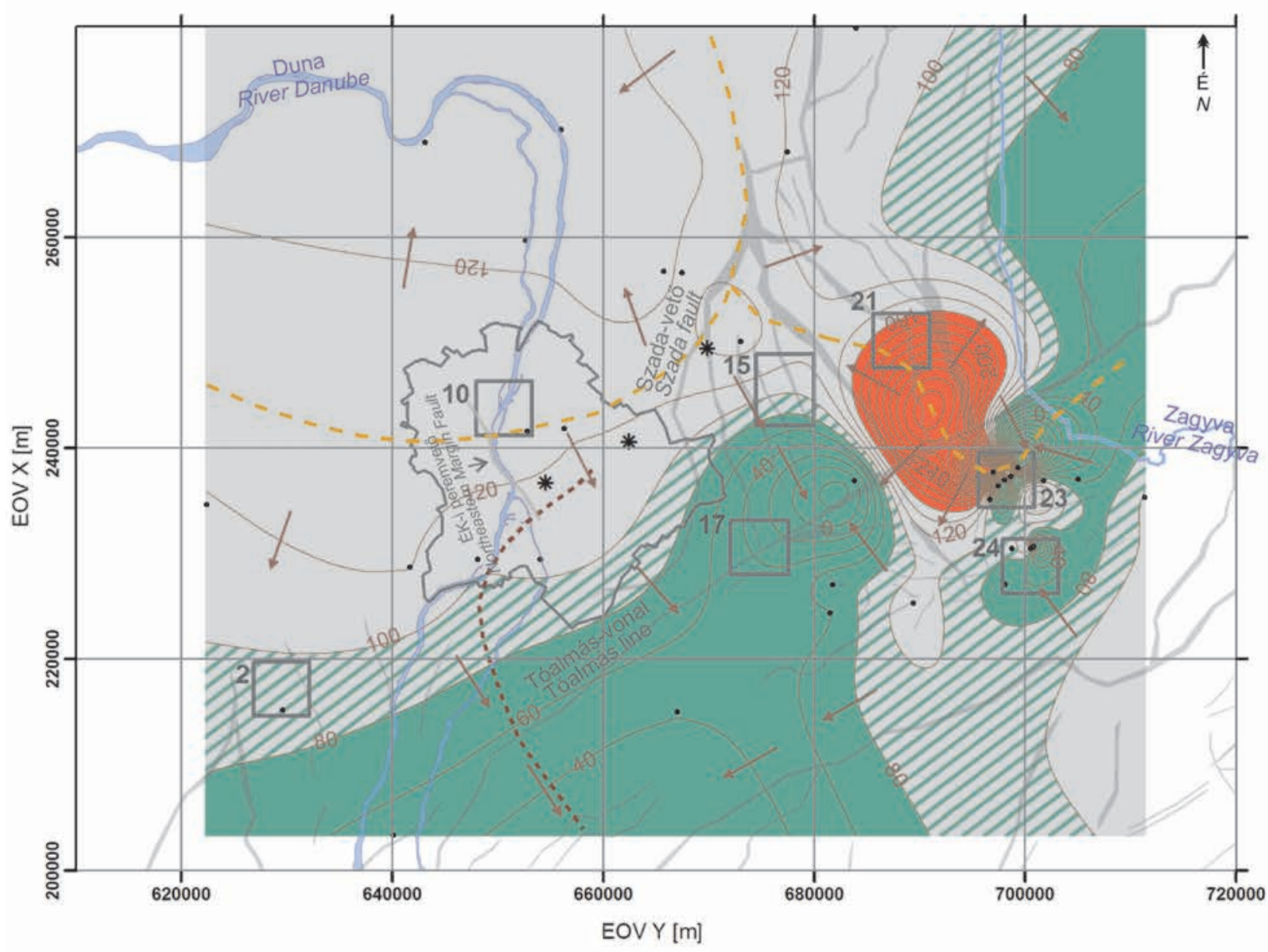

Ey Budapest

folyók

rivers

vetök

faults

ekvipotenciálok (mBf) equipotential lines ( $m$ asl)

felszín alatti vízválasztó groundwater divide

potenciál süllyedék potential depression

hidraulikai adatpontok hydraulic data

horizontális áramlási irány horizontal flow direction
* karbonátos közetre szürözött meddö hévízkutak barren thermal water wells screened for carbonate rocks

$\square^{15} \mathrm{p}(\mathrm{z})$ profilok helye, száma location and number of $p(z)$ profiles

potenciometrikus felszin ( $\mathrm{mBf}$ ) potenciometric surface ( $m$ asl)

$<=80 \mathrm{~m}$ - alulnyomás

$<=80 \mathrm{~m}$ - underpressure

80-100 $\mathrm{m}$ - (átmeneti) alulnyomás

80-100 m - transition between underpressure and close to hydrostatic pressure

100-160 m - hidrosztatikus-közeli nyomás

100-160 m-closed to hydrostatic pressure

$>=160 \mathrm{~m}$ - túlnyomás

$>=160 \mathrm{~m}$ - overpressure

8. ábra. Anomáliák (alul- és túlnyomás) és normál nyomásrezsimek a potenciáltérben a $\mathrm{z}<-1000 \mathrm{mBf}$ szintben a HCS1-2 Vizvezetőre szủrỏzött kutak potenciáladatai alapján (MÁdLNÉ SZŐNYI 2019)

Figure 8. Anomalies (under-and overpressure) and normal pressure regimes in the fluid-potential field below $1000 \mathrm{~m}$ asl based on the hydraulic data of wells screened for the HCS1-2 Aquifer (MÁDLNÉ SZÖNYI 2019) 
zitásfejlődési folyamatokat, így a jelenleg is zajló hipogén karsztosodási folyamatokat (pl. ERőss et al. 2011, 2012a, b; ÖTVÖs et al. 2017; KovÁcs-BODOR et al. 2018, 2019).

A medencehidraulikai értelmezés kapcsán végzett hőmérsékleti adatfeldolgozás szerint a hőmérséklet-eloszlás a HCS3 Vízfogó hőfelhalmozó hatását tükrözi, míg a sziliciklasztos fedő- és a karbonátos feküképződményekre jellemző gradiensek egy függély mentén is számottevő eltérése különböző hőtranszport folyamatokra utal (MÁDLNÉ SZŐNYI 2019a). Így ezek az eredmények további medenceléptékű transzportmodellezéseket inspiráltak. Az áramlási és transzportmodellezések kimutatták, hogy a domborzatilag vezérelt áramlások mellett a késő-miocéntől máig egyre csökkenő mértékben, de a termikus hajtóerố befolyásával is kell számolni (HAVRIL et al. 2016). Mi több, a jelenlegi állapotra vonatkozó tranziens áramlási és hőtranszport-modellezés erre vonatkozó kvantitatív eredményekkel is szolgált (SzIJÁRTó et al. 2019b). Ezek a medenceléptékú modellezések a valós vízáramlási rendszermodellből indulnak ki, és validálásuk is a medencehidraulikai és hőmérsékleti adatfeldolgozáson alapul (3. ábra).

\section{Bakony, Balaton-felvidék, Tihanyi-félsziget}

A Dunántúli-középhegységen belül a Bakony és a Balaton-felvidék, valamint a Tihanyi-félsziget (4. ábra) vízáramlási rendszereinek kutatása az utóbbi tíz évben került érdeklődésünk középpontjába. Itt olyan alapkutatási kérdések merültek fel, mint a Bakony-Balaton-felvidék rendszer és a Balaton lehetséges összefüggései, a források hierarchizáltsága és annak vízáramlási oka, továbbá a tihanyi tavakés a felszín alatti vízáramlások kapcsolata. A vastag karbonátos víztartókra kidolgozott hipotézismodellünk az itteni kutatásokhoz is jó kiindulási alapot szolgáltatott (MÁDL-SzŐNYI \& TóTH 2015) (7. ábra)

Hidraulikus folytonosság és a források hidraulikai jelentôsége

A Bakony és a Balaton-felvidék hidrogeológiailag egy komplex, fedetlen, karbonátos vízadó rendszerként kezelhetô (TóTH \& MÁDL-SzŐNYI 2016). A rendszer hidraulikus folytonosságát és az utánpótlás által vezérelt regionális vízszintkülönbségek okozta vízáramlási rendszerek múködését hidraulikai adatok medenceléptékú elemzésével TóTH (2018) bizonyította. Az itt elvégzett medencehidraulikai feldolgozás módszertani újszerúségét nemcsak a karbonátos rendszerre való alkalmazás, hanem a kisszámú kútadat mellett a források adatainak (az összes hidraulikai adat 57\%-a) a hidraulikai értékelésbe történő bevonása is jelentette. Mivel a források az áramlási rendszerek végpontjait tükrözik (ТóTH 2009b) (2. ábra), így a felszínalatti víztükör természetes megnyilvánulásainak tekinthetôk, és fakadási szintjük megfeleltethető a hidraulikus emelkedési magasságnak (TóTH 2018).

\section{Vízáramlási rendszerek}

A területen elvégzett medencehidraulikai, vízkémiai és hômérsékleti adatelemzés kimutatta, hogy az utánpótlásvezérelt, gravitációs felszín alatti vízáramlások itt is közel hid- rosztatikus nyomásviszonyokat idéznek elő. Ennek hatására az áramló vizek a Bakony beáramlási területeitôl ÉNy és DK felé az alacsonyabb térszínek irányába tartanak. Hierarchizált áramlások 150-200 mBf szintig fordulnak elő, ennél nagyobb mélységben a horizontális áramlások dominanciája mutatható ki. A Bakony és a Balaton-felvidék között kétirányú a hidraulikai kapcsolat: felszínközelben (>250mBf) a Balaton-felvidék felől szivárog víz a Bakony felé, ennél nagyobb mélységben viszont ellentétes irányban, a Balaton felé zajlik a vízmozgás. Továbbá sikerült bizonyítani, hogy a Bakony és Balaton-felvidék felszín alatti vizei is megcsapolódnak a Balaton északi partja mentén és a Balatonban. Emellett a térség felszíni vízfolyásai is szállítanak felszín alatti eredetû vizet, így összességében közel 25\%-ban járulnak hozzá a felszín alatti vizek a tó vízkészletéhez (TóTH 2018, То́тн et al. 2020). A mélyebb regionális áramlások a Balaton medencéje alatt továbbhaladnak déli irányba. Ott a Somogyidombságból érkező felszín alatti vízáramlásokkal találkozva a két oldal közti hajtóerő-különbség eredményeként itt is aszimmetrikus áramkép alakul ki (TóTH \& MÁDL-SzÓNYI 2019). A medencehidraulikai feldolgozás alapján megismert valós vízáramlási rendszermodellt (3. ábra) két, a Bakonyt és Balaton-felvidéket harántoló, ÉNy-DK csapású szelvény mentén végzett numerikus áramlásszimuláció és a kapcsolódó felszíni jelenségek értelmezése révén validáltuk (TóTH 2018). A hidraulikai, hőmérsékleti és vízkémiai adatelemzés, valamint áramlási és hőtranszport-modellezés (ekvivalens porózus közeg megközelítéssel) eredményeként egy új, a BakonyBalaton-felvidék-Balaton rendszerre vonatkozó, felszín alatti vízáramlási modellt sikerült megalkotni (9. ábra) (ТóTH \& MÁDL-SzŐNYI 2019. TóTH et al. 2020).

\section{A Tihanyi-félsziget és a tavak hidraulikai helyzete}

Érdemes kiemelni a vizsgálati területen belül a Tihanyifélszigetet, amelynek felszín alatti vízáramlási rendszereit részletesen tanulmányoztuk (Tóтн et al. 2016). Itt a kútadatok és a források szinte teljes hiányában felszíni elektromágneses geofizikai mérések és a tavak körül létesített potenciométerek alapján határoztuk meg a 3D numerikus áramlásszimulációhoz szükséges hidrosztratigráfiai felépítést, geometriát és peremfeltételeket. A numerikus szimuláció alapján levezetett 3D áramképet a felszín alatti vízáramlások által előidézett felszíni jelenségek előfordulása segítségével (3. ábra) validáltuk. A Tihanyi-félszigeten kialakult áramlási rendszerek a Bakony és Balaton-felvidék felől érkező megcsapoló-átáramló felszín alatti vízáramlásba fészkelődnek, és hidraulikusan alátámasztott helyzetben vannak nagyjából -200 mBf eleváció szint fölött (TóтH 2018). Az áramképet tekintve a félsziget topográfiai magaslatai lokális és intermedier áramlások utánpótlódási területeiként szolgálnak, míg a fő megcsapoló a Balaton, a tihanyi „tavak” (Külső- és Belső-tó, Rátai-csáva) pedig vízszintjüktől függő hidraulikai kapcsolatban állnak egymással, de rátáplálnak a Balatonra is. Ezáltal bizonyítottuk, hogy a tihanyi vizes élőhelyek felszín alatti víztől függő ökoszisztémák (FAVÖKO-k) (TóтH et al. 2016), amelyek hidraulikai helyzetüktől függően eltérő mértékben érzéke- 


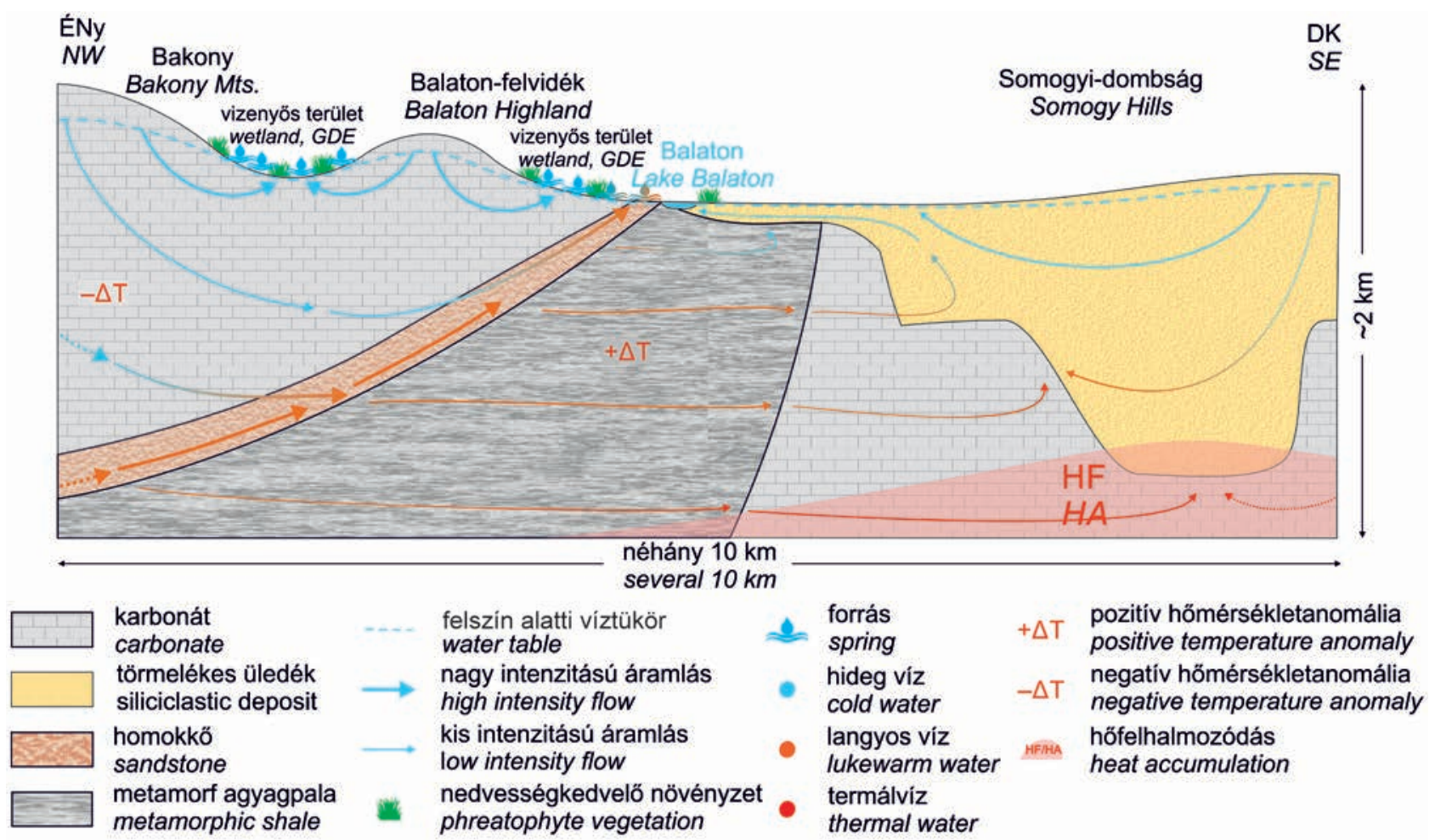

9. ábra. A Bakony-Balaton-felvidék-Balaton rendszer felszín alatti vízáramlásainak, valamint a kapcsolódó folyamatoknak és jelenségeknek elvi vázlata (TóTH \& MÁDL-SZŐNYI 2019)

Figure 9. Generalized model of the groundwater flow systems and the related processes and phenomena in the Bakony-Balaton Highland - Lake Balaton system (TóTH \& MÁDL-SZÖNYI 2019)

nyek a klímaváltozás (csapadék, hőmérséklet, evapotranszspiráció) hatásaira (HAVRIL et al. 2018).

\section{Dráva-medence, Mecsek és Villányi-hegység}

Gravitációs és túlnyomásos rendszerek

A Dráva-medence magyarországi részének medencehidraulikai kutatása a Magyar Horizont Energia Kft. megbízásából kezdődött. Ezt egy PD OTKA kutatás keretében kiterjesztettük egészen a Mecsekig és a Villányi-hegységig (4. ábra). A fô kérdés ismét a pannóniai képződmények regionális hidraulikai viselkedése volt. Ugyanakkor lokális jelenségeket is értelmeztünk a regionális áramlási képbe helyezve a Villányi-hegység déli előterében. Ez a terület a fedetlen és kapcsolódó fedett karbonátos víztartó rendszerek peremterületeinek újabb példájaként szolgált (CsONDOR et al. 2020).

A medencehidraulikai értelmezés eredményeként a felszíntől -500 mBf elevációs szintig vízszintkülönbségek által vezérelt gravitációs áramlási rendszereket tudtunk kimutatni. A - 500 - (-1000) mBf elevációintervallumban már a laterális áramlások dominálnak gyenge feláramló vertikális komponenssel. Ezek a hegy- és dombvidékektől a Dráva és Duna irányába zajló dél-délkeleti áramlásirányt, valamint továbbra is a gravitációs hajtóerőt reprezentálják. A -1500 (-2000) mBf elevációintervallumban kimutatott átmeneti zóna alatt azonban már a korábban vizsgált medencékhez hasonlóan (a Paleogén-medence kivételével) egy túlnyomá- sos tartomány (maximum 66\% túlnyomás) jelentkezik a Dráva-medence (magyarországi részének) északnyugati felében. Ezen belül a feláramlás dominál a vertikális áramlási komponens tekintetében. A laterális áramlások a mélyebb medencerészektől azok peremei felé mutatnak, jellemzően északkeleti és keleti irányba. A túlnyomás lecsengésében itt is meghatározónak bizonyult az Algyối Vízfogó szerepe. Az eredmények gyakorlati alkalmazhatóságát tekintve lehatároltunk egy szénhidrogének hidraulikai csapdázódására alkalmas területet és elevációintervallumot a Dráva-medence északnyugati részén. Ez képezi a szénhidrogének vertikális migrációjának felsố hidraulikai határát, amit a területen ismert szénhidrogén-előfordulások helyzete is alátámaszt.

\section{Vízáramlási komponensek}

A Dráva-medence délkeleti feléből hidraulikai adat csak a felszíntől-200 mBf elevációs szintig állt rendelkezésre, így az ennél mélyebb áramlási tartományról csak analógia alapján tudtunk következtetéseket levonni. A medence északnyugati és délkeleti fele közt nincs jelentős (víz)földtani eltérés a rétegsort és a fejlődéstörténetet tekintve. Így a mélységi túlnyomásos tartomány jelenléte a délkeleti részben is valószínúsíthetô. Ezt támasztja alá, hogy a feltételezett mélységi túlnyomás hatására a medence központi részeitôl a peremei felé tartó -,,medenceeredetư” - fluidumok hatásai a Villányi-hegység déli előteréből, különösen Harkány térségéből ismert hidraulikai, vízkémiai és barlangképződési jelenségekben is kimutathatók (10. ábra). Ezek alapján a 


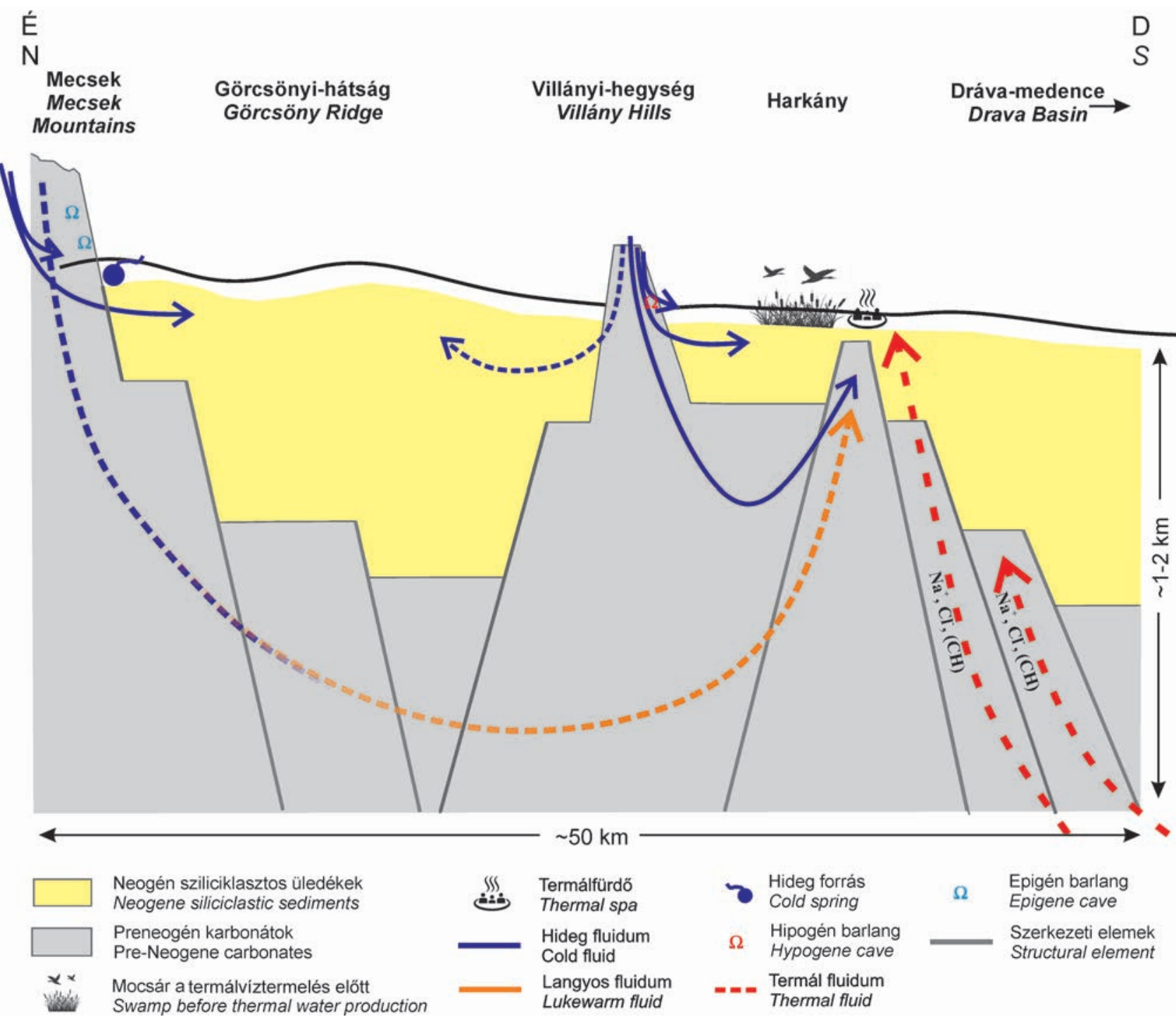

10. ábra. A felszín alatti vízáramlások, valamint a kapcsolódó folyamatok és jelenségek elvi vázlata Harkány térségében (CsoNDOR et al. 2020 után módosítva) Figure 10. Generalized flow field model of the Harkány area with the related processes and phenomena (after CSONDOR et al. 2020)

Villányi-hegység déli előterének kiáramlási területein megcsapolódó felszín alatti vizeknek van egy meteorikus eredetû „,karsztvíz” komponense, amelynek utánpótlódási területeit a Villányi-hegység fedetlen pretercier karbonátjai képezik. Ugyanakkor a medencehidraulikai értelmezés alapján Harkánynál a Mecsek felől érkező regionális áramlások „hidrotermális” fluidumjainak megcsapolódása is valószínúsíthetô. Ezek mellett Harkánynál feltételezhető a „medencekomponens" is. Ez megmutatkozik a termálvíz kémiai összetételében ( $\mathrm{Ca}-\mathrm{Na}, \mathrm{HCO}_{3}$-Cl-SO $\mathrm{SO}_{4}$-fácies magas klorid és nátrium tartalommal), ami átmenetet képez a karsztvizek $\mathrm{Ca}-\mathrm{Mg}, \mathrm{HCO}_{3}$ és a Dráva-medence északnyugati részéből kimutatható Na-K, Cl- $\mathrm{SO}_{4}-\mathrm{HCO}_{3}$-fáciesú „,medencekomponens" közt. Továbbá egy kimutatott pozitív hidraulikai (folyadékpotenciál) anomália intenzív vetô menti feláramlásra utal. Ezen jelenségek kialakulása éppen Harkánynál feltehetően azzal is magyarázható, hogy a Villány-hegység déli elôterén belül ez a terület van legközelebb a Dráva- medence pereméhez. Mindezek alapján Harkány térségében is számolhatunk a fedett és fedetlen karbonátos peremterületekre a BTK-analógia alapján (MÁDLNÉ SzŐNYI et al. 2018) azonosított fluidumkomponensekkel. Azonban a karsztvíz és medenceeredetû fluidum keveredési zónájának kiterjesztése Harkánytól keletre, tehát a teljes Villányelőtérre a recens vízkémiai és hőmérsékleti adatok alapján nem indokolható.

\section{Barlangképződési következmények}

A medencehidraulikai eredményeket itt is felhasználtuk a vízáramlási jelenségek értelmezésére (3. ábra). Földtani időskálán vizsgálva a barlangképződési jelenségek arra utalnak, hogy a fejlődéstörténet korábbi szakaszaiban intenzívebb lehetett a medenceeredetú feláramlás, ami az északról érkező karsztvízzel együtt generált keveredési korrózió révén hipogén barlangok kialakulását eredményezte. Ezek a barlangok magasabb rendú áramlási rendszerek kiáramlási 
területeire jellemzőek (KLIMCHOUK 2007) ott, ahol a fedettség és medencekomponens hatásával is számolni lehet (MÁDL-SZÓNYI \& TÓTH 2015) (7. ábra). Azonban a Villányi-hegység déli előterében a hipogén barlangok ma már átáramlási területeken, fedetlen és sekély helyzetû fedett karbonátokban találhatók, gyakran a talajvíztükör szintje felett. Mindezek, valamint a recens vízkémiai és hőmérsékleti adatok szerint Harkánytól keletre már nem azonosítható fluidumkeveredési zóna. Ennek alapján e hipogén barlangok képződése nem köthető a jelen áramlási rendszerekhez, hanem a medencefejlődés valamely korábbi szakaszához, amikor a gravitációs vízáramlások intenzitása kisebb, a medenceeredetú áramlásoké pedig nagyobb mértékú volt a mainál. Később a gravitációs áramlások dominanciája a Mecsek és Villányi-hegység kiemelkedésével és a pretercier karbonátok - mint utánpótlódási területek - exhumálódásával megerősödhetett. Így a medenceeredetú áramlások viszszább szorulásával a hipogén barlangképződés egyelőre befejeződött. Ezt a folyamatot a Beremendi-kristálybarlang esetén ERőss et al. (2020) vízkémiai és izotóp $\left(\delta^{2} \mathrm{H}, \delta^{18} \mathrm{O}\right)$ mérésekkel, valamint numerikus áramlás- és hőtranszportmodellezéssel is alátámasztotta. Érdemes megjegyezni, hogy az analógiaként kezelhető BTK területén - ahol ráadásul a részleges fedettség a budai oldalon is fennáll - ma is aktívak a hipogén barlangképződési folyamatok. Így bár a medenceeredetű feláramlás itt is erősebb lehetett a fejlődéstörténet korábbi szakaszaiban (Poros et al. 2012), de még most is intenzívebb, mint a recens Villányi-hegység-Drávamedence rendszerben.

\section{Összegzés és kitekintés}

Az ELTE-n folyó medencehidraulikai kutatások az utóbbi két évtizedben beépültek a hazai földtani kutatásba. Munkánk során az 1950-es évektől kezdődő hazai empirikus medencehidraulikai kutatások eredményeiből indultunk ki, majd építettünk a nemzetközi tapasztalatokra, és az ún. „Tóthiskola" hazai képviselőjévé váltunk. Múködésünk során a medencehidraulikai alapelveket alkalmaztuk, de egyúttal elméleti és módszertani értelemben tovább is fejlesztettük a kezdeti eljárásokat. Kutatási tevékenységünket a Pannon-medencében folytatva és közben nemzetközi kapcsolatokat építve, a hazai területekre vonatkozó eredmények a publikációink révén szervesen beépültek a nemzetközi szakmai ismeretanyagba, ezzel is öregbítve a hazai földtan nemzetközi hírnevét.

A bemutatott eredmények alapkutatási jelentőségén túl többször is utaltunk gyakorlati alkalmazhatóságukra, melyet fontos kiemelni. A kezdeti empirikus magyarországi medencehidraulikai értelmezéseket követően az utóbbi évtizedek nagy, medenceléptékú modellezései már építettek ezekre az eredményekre és számos gyakorlati kérdés és megoldás alapjául szolgáltak a vízbázisvédelemtôl a geotermikus energia hasznosításáig (TóTH et al. 2016, SzŐCs et al. 2018 stb.). Megállapítható, hogy a legtöbb hazai és régiós kutatás gyakorlati indítékú regionális munka, melyben alap- kutatási kérdések is felmerülnek, de céljuk többnyire gyakorlati feladatok hatékony megoldása. Ezekhez alap-, ill. felfedezô medencekutatással járul hozzá az ELTE. A kutatások szisztematikusan fejlesztett megközelítésen alapulnak, a természetes vízáramlási rendszerek megértése, hipotézis-alkotás, következetes medencehidraulikai feldolgozás, valós vízáramlási rendszermodell" kialakítása, az áramlások által előidézett jelenségek és a numerikus modellezés szerves egységét kialakítva (3. ábra). Azaz munkánk során egyrészt a medencehidraulikai módszertan fejlesztése zajlik, másrészt olyan elméleti kérdéseket elemzünk, mint a különböző fluidum hajtóerők és azok kölcsönhatásai. De célzott figyelmet kapnak a fluidum-kőzet kölcsönhatás révén kialakult jelenségek, melyek végtelen tárháza kapcsolható a vízáramlásokhoz. Így a bemutatott szikesedés, barlangképződés, szénhidrogén-csapdázódás, biogeokémai kiválások és még sok egyéb. E jelenségek, valamint a vízáramlási rendszerek és a numerikus elemzések összekapcsolása további összefüggések felismerését teszik lehetôvé a jövőben. Végezetül ezen eredmények sajátossága, hogy a Pannon-medence „kutatólaboratóriumában” kerülnek leírásra és bemutatásra. Így válhatott a Tihanyi-félsziget a félsziget jellegú vízáramlási rendszerek típusterületévé vagy a BTK a vastag fedett és fedetlen karbonátos víztartó rendszerek és áramlási rendszereik nemzetközileg elismert mintaterületévé.

A hidrogeológiai fejlődési trendekből kiindulva a jövőben várhatóan egyre több alkalmazási területtel foglalkozunk. Így az utóbbi évek újdonságai például a felszín alatti vizek radionuklid-tartalmának vízáramlási szemléletú értékelése, de a mesterséges vízpótlás, azaz a MAR-ok (Managed Aquifer Recharge) kérdései, de a biogén (szénhidrogén) gázok felszín alatti vízáramlás kontrollálta migrációjának és csapdázódásának kérdései is ide sorolhatók. 2018-ban indult hároméves kutatás a geofluidumok és az azokhoz kapcsolódó erőforrások (felszín alatti víz, geotermikus energia, hidrotermális ércesedések) rendszerszemléletú értékelésére ENeRAG (Excellency Network Building for Comprehensive Research and Assessment of Geofluids H2020) címen. A projekt célja az ELTE (mint konzorciumvezető) kutatási és innovációs kapacitásának további erősítése nemzetközi kiválósági központ létrehozásával és hálózatépítéssel a felszín alatti fluidumok oktatása és kutatása területén. Célunk a felszín alatti víz, valamint a geotermikus és hidrotermális fluidumok összefüggéseinek jobb megértése, ezáltal a fenntartható kinyerésükre alkalmazott - vízgazdálkodási, geotermikus energiahasznosítási, ásványi nyersanyag feltárási és hasznosítási - technológiák hatékony fejlesztése.

Az elmúlt húsz év kutatási eredményeinek oktatásfejlesztési hasznosulása is látható a CHARM (Challengedriven, Accessible, Research-based, Mobile) European University (CHARM-EU) „Víz” témájú mesterszakos programjában is, mely pilot képzés nemzetközi kooperációban 2021-től indul meg egyetemünkön. Emellett az ismeretek kommunikációjára is egyre nagyobb figyelmet fordítunk, ezért indítottuk el magyar és angol nyelvú blogjainkat 
(https://felszinalattiviz.blogspot.com/; https://geofluids.blogspot com/). A jövő tehát egyre több lehetőséggel és feladattal kecsegtet a medencehidraulikai kutatás, oktatás és tudáskommunikáció terén is, ami a globális vízválság korában különös jelentőséggel bír és egyúttal felelősséget is jelent.

\section{Köszönetnyilvánítás}

A cikk szerzői ezúton mondanak köszönetet mindazoknak a hazai elődöknek, akik Magyarországon lefektették az empirikus medencehidraulika alapjait, közülük is kiemelten ERDÉLYI Mihálynak. TóTH József professzornak köszönjük, hogy hazahozta tudását Kanadából és megosztotta a magyar szakemberekkel. MinDSZENTY Andrea egykori tanszékvezetó jóindulatú támogatása és Tóth professzor folyamatos segítsége folytán az ELTE lehetett az az intézmény, ahol a medencehidraulika elismert kutató és képző helye kialakult. Köszönjük továbbá mindazoknak, akik az elmúlt húsz évben munkájukkal hozzájárultak az elvégzett és itt bemutatott kutatások megvalósításához. ERHARDT Ildikónak köszönjük az ábrák elkészítése kapcsán nyújtott segítségét. Dr. SzANYI János szakszerkesztőnek, Dr. ALMÁsI Istvánnak és két további lektornak köszönjük az építő jellegú kritikákat. A cikk az ENeRAG-projekt keretein belül készült, amelyet az Európai Unió Horizont 2020 kutatási és innovációs programja támogatott a 810980 azonosító számú támogatási megállapodás alapján.

\section{Irodalom - References}

ALFÖLDI L. 1979: Budapesti hévizek. - VITUKI kiadvány, Budapest, 102 p.

ALFÖLDI L. 1981: A budapesti geotermikus áramlási rendszer modellje. - Hidrológiai Közlöny 9, 1-7.

AlföLdI L. \& KAPOLYI L. (szerk.) 2007: Bányászati karsztvízszintsüllyesztés a Dunántúli-középhegységben. - Magyar Tudományos Akadémia Földrajztudományi Kutatóintézet, Budapest, 139 p.

AlMÁsI, I. 2001: Petroleum Hydrogeology of the Great Hungarian Plain, Eastern Pannonian Basin, Hungary. - PhD Thesis, University of Alberta, Department of Earth and Atmospheric Sciences, Edmonton, Alberta, 312 p.

ALMÁsI, I. 2003: Evaluation of the possible mechanisms able to generate and maintain the overpressured regime in the Pannonian Basin, Eastern Hungary. - Journal of Geochemical Exploration 78-79, 139-142. https://doi.org/10.1016/s0375-6742(03)00084-0

BACK, W. 1966: Hydrochemical facies and ground-water flow patterns in northern part of Atlantic Coastal Plain. - USGS Professional Paper 498-A, 42 p. https://doi.org/10.3133/pp498A

BALoGH V. 2016: A Duna-Tisza köze áramlási rendszereinek és a hajtóerôk szerepének vizsgálata numerikus modellezéssel. Szakdolgozat, ELTE TTK Általános és Alkalmazott Földtani Tanszék, Budapest, 103 p.

BALOGH, V., Simon, Sz. \& Tóth, Á. 2017a: Role of fluid driving forces in large sedimentary basins - case study from the Pannonian Basin, Hungary. - In: Posavec, K. \& MARKovic, T. (eds): 44th Congress of International Association of Hydrogeologists - Book of abstracts. Paper: T3.4.22.

BALOGH, V., Tóth, Á. \& SimOn, Sz. 2017b: Effect of different driving forces in large sedimentary basins. - In: SMERDON, B., TóTH, Á. \& MÁDL-SzŐNYI, J. (eds): Characterizing regional groundwater flow systems: Insight from practical applications and theoretical development: Symposium Agenda and Abstracts, $36 \mathrm{p}$.

BRACE, W. F. 1980: Permeability of crystalline and argillaceous rocks. - International Journal of Rock Mechanics and Mining Sciences 17, 241-251. https://doi.org/10.1016/0148-9062(81)90784-1

BREDEHOEFT, J. D. 2018: The Toth Revolution. - Groundwater 56/1, 157-159. https://doi.org/10.1111/gwat.12592

CARDENAS, M. B. \& JiANG, X. W. 2010: Groundwater flow, transport, and residence times through topography-driven basins with exponentially decreasing permeability and porosity. - Water Resources Research 46/11, W11538. https://doi.org/10.1029/ 2010wr009370

CHAMBERLAIN, T. C. 1885: The requisite and qualifying conditions of artesian wells. - US Geological Survey $5^{\text {th }}$ Annual Report, 131-175.

CZAUnER, B. 2012: Regional hydraulic function of structural elements and low-permeability formations in fluid flow systems and hydrocarbon entrapment in eastern-southeastern Hungary. - PhD disszertáció, ELTE TTK Általános és Alkalmazott Földtani Tanszék, Budapest, 189 p.

CZAUNER B. \& MÁDL-SZŐNYI J. 2008: A berekfürdői mélyszerkezet és vízföldtani vonatkozásai. - Hidrológiai Tájékoztató 48/1, 32-34.

CZAUNER, B. \& MÁDL-SZŐNYI, J. 2011: The function of faults in hydraulic hydrocarbon entrapment: Theoretical considerations and a field study from the Trans-Tisza region, Hungary. - AAPG Bulletin 95/5, 795-811. https://doi.org/10.1306/11051010031

CZAunER, B. \& MÁDL-SzŐNYI, J. 2013: Regional hydraulic behavior of structural zones and sedimentological heterogeneities in an overpressured sedimentary basin. - Marine and Petroleum Geology 48, 260-274. https://doi.org/10.1016/j.marpetgeo.2013.08.016

CZAUner, B., MÁDL-SzŐNYI, J., ERŐss, A. \& VoJNITS, A. 2008: Mapping vegetational and salinization phenomena to evaluate the extent of Lake Kelemenszék. - Central European Geology 51/3, 231-240. https://doi.org/10.1556/ceugeol.51.2008.3.5

CZAuner, B., MÁdl-SzŐNYI, J., TóTH, J. \& PogÁCSÁs, Gy. 2008: Hydraulic potential anomaly indicating thermal water reservoir and gas pool near Berekfürdő, Trans-Tisza Region, Hungary. - Central European Geology 51/3, 253-266. https://doi.org/10.1556/ ceugeol.51.2008.3.7

CsOndor, K., CZAuner, B., CsOBAJI, L., GYŐRI, O. \& Erôss, A. 2020: Characterization of the regional groundwater flow systems in south 
Transdanubia (Hungary) to understand karst evolution and development of hydrocarbon and geothermal resources. - Hydrogeology Journal 28, 2803-2820. https://doi.org/10.1007/s10040-020-02216-9

DARCY, H. 1856: Les fontaines publiques de la ville de Dijon. - Victor Dalmont, Paris.

DEMING, D. 2002: Introduction to hydrogeology. - McGraw-Hill, New York, 480 p.

Dickson, M. H. \& FAnelli, M. 2013: Geothermal Energy: Utilization and Technology. - Routledge, London, 224 p. https://doi.org/ $10.4324 / 9781315065786$

Engelen, G. B. 2013: Hierarchically nested energy flow systems of planet Earth. - Proceedings of the International Symposium on Regional Groundwater Flow: Theory, Applications and Future 116 Development, Xi'an, China, 21-23 June 2013, China Geological Survey, Commission on Regional Groundwater Flow, IAH 225.

Engelen, G. B. \& Kloosterman, F. H. 1996: Hydrological systems analysis: methods and applications. - Kluwer, Dordrecht, 152 p.

ERDÉLYI, M. 1976: Outlines of the hydrodynamics and hydrogeochemistry of the Pannonian Basin. - Acta Geologica Academiae Scientiarium Hungaricae 20/3-4, 287-309.

ERhardt, I., ÖtvÖs, V., ERôss, A., CzAuner, B., Simon, Sz. \& MÁdL-SzŐnYi, J. 2017: Hydraulic evaluation of the hypogenic karst area in Budapest (Hungary). - Hydrogeology Journal 25/6, 1871-1891. https://doi.org/10.1007/s10040-017-1591-3

ERőss, A., MÁdL-SzŐNYI, J. \& Csoma, A. É. 2008: Characteristics of discharge at rose and Gellért Hills, Budapest, Hungary. - Central European Geology 51/3, 267-281. https://doi.org/10.1556/ceugeol.51.2008.3.8

ERôss, A., Poros, Zs., Mádl-Szônyi, J., Mindszenty, A., Molnár, F., Ronchi, P. \& Csoma, A. É. 2011: Role of karstic and basinal fluids in porosity evolution in the Buda Hills, Hungary. - AAPG International Conference and Exhibition 2011: Following DaVinci's Footsteps to Future Energy Resources: Innovations from Outcrops to Assets AAPG, Paper 1071554.

ERŐss, A., MÁDL-SzŐNYI, J. \& CsOMA, A. É. 2012a: Hypogenic karst development in a hydrogeological context, Buda Thermal Karst, Budapest, Hungary. - Groundwater quality sustainability: IAH selected papers on hydrogeology 17, 119-133. https://doi.org/ $10.1201 / \mathrm{b} 12715-12$

ERŐss, A., MÁdL-SzŐNYI, J., SurbeCK, H., HorvÁth, Á., GoldSCHEIdER, N. \& CsOMA, A. É. 2012b: Radionuclides as natural tracers for the characterization of fluids in regional discharge areas, Buda Thermal Karst, Hungary. - Journal of Hydrology 426-427, 124-137. https://doi.org/10.1016/j.jhydrol.2012.01.031

Eróss, A., Csondor, K., CzupPon, Gy., Dezsó, J. \& MÜLler, I. 2020: Groundwater flow system understanding of the lukewarm springs in Kistapolca (South Hungary) and its relevance to hypogene cave formation. - Environmental Earth Sciences 79, Article number: 132, 15 p. https://doi.org/10.1007/s12665-020-8870-3

Európai Parlament \& Az Európai Unió Tanácsa 2000: Az Európai Parlament és a Tanács 2000/60/EK irányelve (2000. október 23.) a vízpolitika terén a közösségi fellépés kereteinek meghatározásáról. - Official Journal L 327, 22/12/2000, p. 1-73, Special edition in Hungarian Chapter 15, Volume 005 P. 275 - 346.

FOURMARIER, P. F. J. 1939: Hydrogéologie. - Masson, Paris.

Freeze, R. A. \& WithersPoOn, P. A. 1966: Theoretical analysis of regional groundwater flow: 1. Analytical and numerical solutions to the mathematical model. - Water Resources Research 2/4, 641-656. https://doi.org/10.1029/wr002i004p00641

FreEZE, R. A. \& WitherSPOON, P. A. 1967: Theoretical analysis of regional groundwater flow: 2. Effect of water table configuration and subsurface permeability variation. - Water Resources Research 3/2, 623-634. https://doi.org/10.1029/wr003i002p00623

FreEZE, R. A. \& WithERSPOON, P. A. 1968: Theoretical analysis of regional groundwater flow: 3. Quantitative interpretations. - Water Resources Research 4/3, 581-590. https://doi.org/10.1029/wr004i003p00581

GALSA, A., SZIJÁRTó, M., TÓTH, Á., LENKEY, L. \& MÁDL-SZŐNYI, J. 2019: Interaction of topography-and salinity-driven groundwater flow in synthetic numerical models and a real geological situation. - Geophysical Research Abstracts 21, EGU2019-9960, 2019.

Garamhegyi, T., SzÉKely, F., CARRILlo-Rivera, J. J. \& MÁDl-SzŐNYI, J. 2020: Revision of archive recovery tests using analytical and numerical methods on thermal water wells in sandstone and fractured carbonate aquifers in the vicinity of Budapest, Hungary. Environmental Earth Sciences 79, Article no. 129. https://doi.org/10.1007/s12665-020-8835-6

GARVEN, G. 1995: Continental-scale groundwater flow and geologic processes. - Annual Review of Earth and Planetary Sciences 23/1, 89-117. https://doi.org/10.1146/annurev.ea.23.050195.000513

GLEESON, T. \& MANNING, A. H. 2008: Regional groundwater flow in mountainous terrain: threedimensional simulations of topographic and hydrogeologic controls. - Water Resources Research 4/10, W10403. https://doi.org/10.1029/2008wr006848

Goldscheider, N. \& DREw, D. (eds) 2014: Methods in Karst Hydrogeology. - Taylor \& Francis, London, 280 p. https://doi.org/10.1201/ 9781482266023

Goldscheider, N., MÁdl-SzŐNYI, J., ERŐss, A. \& Schill, É. 2010: Review: Thermal water resources in carbonate rock aquifers. Hydrogeology Journal 18, 1303-1318. https://doi.org/10.1007/s10040-010-0611-3

Haitjema, H. M. \& Mitchell-BrukeR, S. 2005: Are water tables a subdued replica of the topography? - Ground Water 43/6, 781-786. https://doi.org/10.1111/j.1745-6584.2005.00090.x

HALÁsZ, G. 1975: A study of the behaviour of orifice in a quasistationary flow. Proceedings of the Fifth Conference on Fluid Machinery. - In: 5th Conference on Fluid Machinery, Proceedings, Volume 1. (A76-22978 09-02). Akadémiai Kiadó, Budapest, 389-392.

HANTUSH, M. S. 1956: Analysis of data from pumping tests in leaky aquifers. - Eos, Transactions American Geophysical Union 37/6, 702-714. https://doi.org/10.1029/tr037i006p00702

HANTUSH, M. S. \& JACOB, C. E. 1955: Nonsteady radial flow in an infinite leaky aquifer. - Eos, Transactions American Geophysical Union 36/1, 95-100. https://doi.org/10.1029/tr036i001p00095

Havril, T., Molson, J. W. \& MÁDL-SzŐNYI, J. 2016: Evolution of fluid flow and heat distribution over geological time scales at the margin of unconfined and confined carbonate sequences - A numerical investigation based on the Buda Thermal Karst analogue. Marine and Petroluem Geology 78, 738-749. https://doi.org/10.1016/j.marpetgeo.2016.10.001 
HaVril, T., Tóth, Á., Molson, J. W., GalSA, A. \& MádL-SzÓNYI, J. 2018: Impacts of predicted climate change on groundwater flow systems: Can wetlands disappear due to recharge reduction? - Journal of Hydrology 563, 1169-1180. https://doi.org/10.1016/ j.jhydrol.2017.09.020

HUBBERT, M. K. 1940: The theory of ground-water motion. - The Journal of Geology 48/8, 785-944. https://doi.org/10.1086/624930

IAH: Strategic Overview Series. https://iah.org/education/professionals/strategic-overview-series Utolsó megtekintés idôpontja: 2020.07 .19$.

Ingebritsen, S., SANFord, W. \& NeuZIL, C. 2006: Groundwater in Geologic Processes. - Cambridge University Press, Cambridge, UK, 536 p.

Jiang, X. W., Wan, L., CARdenas, M. B., Ge, S. \& WANG, X. S. 2010: Simultaneous rejuvenation and aging of groundwater in basins due to depth-decaying conductivity and porosity. - Geophysical Research Letters 37/5, L05403. https://doi.org/10.1029/2010g1042387

JiAng, X. W., WANG, X. S., WAN, L. \& GE, S. 2011: An analytical study on stagnation points in nested flow systems in basins with depthdecaying hydraulic conductivity. - Water Resources Research 47/1, W01512. https://doi.org/10.1029/2010wr009346

JiANG, X.W., CHERRY, J. \& WAN, L. 2020: Flowing wells: history and role as a root of groundwater hydrology. - Hydrology and Earth System Sciences Discussion, in review. https://doi.org/10.5194/hess-2020-270

KAPILLER R. 2016: Hidrogeológiai modellezés a bemenő földtani paraméterek változékonyságának függvényében. - Diplomamunka, ELTE TTK Általános és Alkalmazott Földtani Tanszék, Budapest, 85 p.

KING, F. H. 1899: Principles and conditions of the movement of groundwater. - US Geological Survey Annual Report 19 (Part II), 59-294.

KLImсноuк, A. B. 2007: Hypogene speleogenesis: hydrogeological and morphogenetic perspective. - Special paperno. 1, National Cave and Karst Research Institute, Carlsbad, NM, 106 p.

Kovács-Bodor, P., Anda, D., Jurecska, L., Óvári, M., Horváth, Á., MakK, J. \& Mádl-SzŐNYi, J. 2018: Integration of in situ experiments and numerical simulations to reveal the physicochemical circumstances of organic and inorganic precipitation at a thermal spring. - Aquatic Geochemistry 24/3, 231-255. https://doi.org/10.1007/s10498-018-9341-2

Kovács-Bodor, P., Csondor, K., Erőss, A., Szieberth, D., Freiler-Nagy, Á., Horváth, Á. \& Mádl-SzŐnyi, J. 2019: Natural radioactivity of thermal springs and related precipitates in Gellért Hill area, Buda Thermal Karst, Hungary. - Journal of Environmental Radioactivity 201, 32-42. https://doi.org/10.1016/j.jenvrad.2019.01.020

KovÁCS J. \& MÜLLER P. 1980: A budai-hegyek hévizes tevékenységének kialakulása és nyomai. - Karszt és Barlang 2, 93-98.

KuTi L. \& KőRössy L. 1989: Az Alföld Földtani Atlasza: Dunaújváros-Izsák. - Magyar Állami Földtani Intézet, Budapest, 19 p.

LUSCZYNSKI, N. J. 1961: Head and flow of ground water of variable density. - Journal of Geophysical Research 66/12, 4247-4256. https://doi.org/10.1029/jz066i012p04247

MÁDLNÉ SZŐNYI J. 1997: Víztartó rendszerek sérülékenységi vizsgálata a dunántúli-középhegységi főkarsztvíztároló rendszer (DNy-i rész) példáján. - Földtani Közlöny 1276/1-2, 19-83.

MÁdL-SZŐNYI, J. 2008: The contribution of József Tóth to modernization of Hungarian hydrogeology. - Central European Geology 51/3, 189-201. https://doi.org/10.1556/ceugeol.51.2008.3.2

MÁdLNÉ SzŐNYI J. 2019a: Felszínalatti vízáramlások mintázata fedetlen és kapcsolódó fedett karbonátos viztartó rendszerekben a Budaitermálkarszt tágabb környezetének példáján. - MTA Doktori értekezés, Budapest, 131 p.

MÁDLNÉ SZŐNYI J. 2019b: A regionális pórusnyomásviszonyok jelentôsége a termálvíz feltárásban és a készletek megújulásában. Magyar Tudomány 180/12, 1796-1807. https://doi.org/10.1556/2065.180.2019.12.6

Mádlné SzŐnyi J., Simon Sz., Tóth J. \& Pogácsás Gy. 2005: Felszíni és felszín alatti vizek kapcsolata a Duna-Tisza közi Kelemenszék és Kolon-tó esetében. - Általános Földtani Szemle 30, 93-110.

Mádlné Szônyi J., Erôss A., Havril T., Poros Zs., Győri O., Tóth Á., Csoma A., Ronchi P. \& Mindszenty A. 2018: Fluidumok, áramlási rendszerek és ásványtani lenyomataik összefüggései a Budai Termálkarszton. - Földtani Közlöny 148/1, 75-96. https://doi.org/10.23928/foldt.kozl.2018.148.1.75

MÁDL-SZŐNYI, J. \& SiMON, S. 2016: Involvement of preliminary regional fluid pressure evaluation into the reconnaissance geothermal exploration - Example of an overpressured and gravity-driven basin. - Geothermics 60, 156-174. https://doi.org/10.1016/ j.geothermics.2015.11.001

MÁDL-SZŐNYI, J. \& TótH, Á. 2015: Basin scale conceptual groundwater flow model for an unconfined and confined thick carbonate region. - Hydrogeology Journal 23/7, 1359-1380. https://doi.org/10.1007/s10040-015-1274-x

MÁDL-SzŐNYI, J. \& TóTH, J. 2009: A hydrogeological type section for the Duna-Tisza Interfluve, Hungary. - Hydrogeology Journal 17/4, 961-980. https://doi.org/10.1007/s10040-008-0421-z

MÁdL-SZÓNYI, J., PULAY, E., TÓTH, Á. \& BODOR, P. 2015: Regional underpressure: a factor of uncertainty in the geothermal exploration of deep carbonates, Gödölló Region, Hungary. - Environmental Earth Sciences 74/12, 7523-7538. https://doi.org/10.1007/s12665-015-4608-Z

Mádl-Szônyi, J., Czauner, B., Iván, V., Tóth, Á., Simon, Sz., Erôss, A., Bodor, P., Havril, T., Boncz, L. \& Sőreg, V. 2019: Confined carbonates - Regional scale hydraulic interaction or isolation? - Marine and Petroleum Geology 107, 591-612. https://doi.org/ 10.1016/j.marpetgeo.2017.06.006

MARTON L. 2009: Alkalmazott hidrogeológia. - ELTE Eötvös Kiadó Kft., Budapest, 626 p.

MARTON L. 2012: Az Alföld ásványi kincse a felszín alatti víz. - Magyar Tudomány 2, 206-215.

MARTON L. \& MiKó L. 1989: Izotóp-adatok interpretálása az Alföld hidrogeológiai kutatásában. - Hidrológiai Közlöny 69/1, 50-58.

MARTON L. \& SZANYI J. 2000: A talajvíztükör helyzete és a rétegvíz termelés kapcsolata Debrecen térségében. - Hidrológiai Közlöny 80/1, 2-18.

MAXEY, G. B. 1964: Hydrostratigraphic units. - Journal of Hydrology 2/2, 124-129. https://doi.org/10.1016/0022-1694(64)90023-x

MunN, M. J. 1909: The anticlinal and hydraulic theories of oil and gas accumulation. - Economic Geology 4, 509-529. https://doi.org/ 10.2113/gsecongeo.4.6.509

NeUmAn, S. P. \& WitherSPOON, P. A. 1969a: Theory of flow in a confined two aquifer system. - Water Resources Research 5/4, $803-816$. https://doi.org/10.1029/wr005i004p00803 
Neuman, S. P. \& Witherspoon, P. A. 1969b: Applicability of current theories of flow in leaky aquifers. - Water Resources Research 5/4, 817-829. https://doi.org/10.1029/wr005i004p00817

NeUman, S. P. \& Witherspoon, P. A. 1972: Field determination of hydraulic properties of leaky multiple aquifer systems. - Water Resources Research 8/5, 1284-1298. https://doi.org/10.1029/wr008i005p01284

NeuZIL, C. E. 1994: How permeable are clays and shales? - Water Resources Research 30/2, 145-150. https://doi.org/10.1029/93wr02930

ORSZÁGOS VízÜGYI FốIGAZGATósÁG 2016: Vízgyújtố-gazdálkodási Terv - A Duna-vízgyújtô magyarországi része, 676 p.

Ötvös V., Erhardt I., Erőss A., CZauner B., Simon Sz. \& MádlnÉ SzŐNYi J. 2017: A Budai Termálkarszt hidraulikai viszonyainak barlangképződési vonatkozásai. - Karsztfejlődés 22, 5-33.

Padisák J., Ács É., Borics G., Buczkó K., Grigorszky I., Kovács Cs., Mádlné SzőnYi J. \& Soróczki-Pintér É. 2006: A Víz Keretirányelv és vízi habitatdiverzitás konzervációbiológiai vonatkozásai. - Magyar Tudomány 167, 663-669.

PAPP B. 1974: Felszínalatti vizek oxigén-18 és deutérium összetevőinek regionális vizsgálata. - Kézirat, Budapest.

PETHŐ S., MÁDLnÉ SzŐNYI J. \& TóTH J. 2004: A Kisalföldi-medence regionális felszín alatti gravitációs vízáramlási képe hidraulikai adatfeldolgozás alapján. - Földtani Kutatás 41/2, 13-20.

Poros, Zs., Erőss, A., MÁdl-SzŐNYI, J., MindsZenty, A., MolnÁr, F., Ronchi, P. \& Csoma, E. A. 2010: Mixing of karstic and basinal fluids affecting hypogene cave formation and mineralization in the Buda Thermal Karst, Hungary. - In: ZAHARIA, L., KIS, A. TOPA, B., PAPP, G. \& WeisZBurg, T. (eds): Acta Mineralogica Petrographica Abstract Series, Budapest, 864 p.

Poros, Zs., Mindszenty, A., Molnár, F., Pironon, J., Győri, O., Ronchi, P. \& SzeKeres, Z. 2012: Imprints of hydrocarbon-bearing basinal fluids on a karst system: mineralogical and fluid inclusion studies from the Buda Hills, Hungary. - International Journal of Earth Sciences 101/2, 429-452. https://doi.org/10.1007/s00531-011-0677-8

RoBinson, N. I. \& Love, A. J. 2014: Hidden channels of groundwater flow in Tóthian drainage basins. - Advances in Water Resources 62 , 71-78. https://doi.org/10.1016/j.advwatres.2013.10.004

RÓNAI A. 1963: Az Alföld negyedkori rétegeinek vízföldtani vizsgálata. - Hidrológiai Közlöny 43/5, 378-391.

RÓNAI A. 1975: A talajvíz és rétegvizek kapcsolata az Alföldön. - Hidrológiai Közlöny 55/2, 49-53.

RóNAi A. 1985: Az Alföld negyedidőszaki földtana. - Geologica Hungarica Series Geologica 21, 1-412.

Rostron, B. J. \& TótH, J. 1996: Ascending fluid plumes above Devonian pinnacle reefs: numerical modeling and field example from westcentral Alberta, Canada. - In: SchumaChER, D. \& ABrAms, M. A. (eds): Hydrocarbon migration and its near-surface expression. AAPG Memoir 66, 185-201.

SCHAFARZIK F. 1928: Budapest székesfőváros ásványvízforrásainak geológiai jellemzése és grafikus feltüntetése. - Hidrológiai Közlöny 4-6, 14-20.

SCHMidT Eligius R. \& Almássy E. (szerk.) 1962: Magyarország vízföldtani atlasza. - Magyar Állami Földtani Intézet, 78 p.

Simon, SZ., MÁdL-SZŐNYI, J., MÜLLER, I. \& ZSEMLE, F. 2008: Identification of near-surface saline water in the Lake Kelemenszék area, Danube-Tisza Interfluve, Hungary. - Central European Geology 51/3, 219-230. https://doi.org/10.1556/ceugeol.51.2008.3.4

SimON, Sz., MÁdL-SzôNYI, J., Müller, I. \& PogáCSÁs, Gy. 2011: Conceptual model for surface salinization in an overpressured and a superimposed gravity-flow field, Lake Kelemenszék area, Hungary. — Hydrogeology Journal 19, 701-717. https://doi.org/ 10.1007/s 10040-011-0711-8

Simmons C. T. \& SHARP J. 2001: Variable-density groundwater flow and solute transport in heterogeneous porous media: Approaches, resolutions and future challenges. — Journal of Contaminant Hydrology 52, 245-275. HTTPS://DOI.ORG/10.1016/S0169-7722(01)00160-7

STIFF, H. A. 1951: The interpretation of chemical water analysis by means of patterns. - Journal of Petroleum Technology 3/10, 15-17. https://doi.org/10.2118/951376-g

StUTE, M. \& DEÁK, J. 1989: Environmental isotope study $\left({ }^{14} \mathrm{C},{ }^{13} \mathrm{C},{ }^{18} \mathrm{O}\right.$, D, noble gases) on deep groundwater circulation systems in Hungary with reference to paleoclimate. - Radiocarbon 31/3, 902-918. https://doi.org/10.1017/S0033822200012522

SZANYI J. 2004: Felszín alatti víztermelés környezeti hatásai a Dél-Nyírség példáján. - PhD disszertáció, Szegedi Tudományegyetem, Ásványtani, Kôzettani és Geokémiai Tanszék, Szeged. 88 p.

SZEBÉNYI L. 1955: Ártézi vizek függőleges irányú mozgásáról. - Hidrológiai Közlöny 35/11-12, 437-440.

SZEBÉNYI L. 1965: Az artézi víz forgalmának mennyiségi meghatározása. - Hidrológiai Közlöny 45/3, 125-130.

SZÉKELY F. 1977: Víztermelés hatására kialakuló regionális vízszintsüllyedés számítógépes vizsgálata negyedkori képződményeinkben. - Hidrológiai Közlöny 57/3, 118-125.

SziJÁRTó, M., GAlSA, A., Tóth, Á. \& MÁDl-SzŐNYI, J. 2019a: Numerical investigation of the combined effect of forced and free thermal convection in synthetic groundwater basins. - Journal of Hydrology 572, 364-379. https://doi.org/10.1016/j.jhydrol.2019.03.003

SzIJÁRTó, M., GALSA, A., TóTh, Á., LENKEY, L. \& MÁdL-SzŐNY, J. 2019b: Numerical investigation of the interaction of different driving forces on groundwater flow and temperature pattern in a theoretical basin and in the Buda Thermal Karst, Hungary. - Geophysical Research Abstracts 21, EGU2019-5830, 2019.

SzŐ́cs, T., RMAn, N., Rotár-SZALKaI, Á., Tóth, Gy., LAPANJe, A., ČERnÁK, R. \& NÁDOR, A. 2018: The upper pannonian thermal aquifer: Cross border cooperation as an essential step to transboundary groundwater management. - Journal of Hydrology: Regional Studies 20, 128-144. https://doi.org/10.1016/j.ejrh.2018.02.004

TERZAGHI, K. 1923: Die berechnung der durchlassigkeitsziffer des tones aus dem verlauf der hydrodynamischen spannungserscheinungen. - Akademie der Wissenschaften in Wein, Sitzungsberichte, Mathematisch-naturwissenschaftliche Klasse Part IIa, 132/3-4,125-138. (Reprinted in Bjerrum, L., Cassagrande, A., Peck, R. B. \& Skempton, A. W. [eds] 1960: From Theory to Practice in Soil Mechanics. John Wiley, New York, 133-146).

TóTH Á. 2018: A Balaton-felvidék felszínalatti vizeinek hidraulikai kapcsolata a Bakonnyal és a Balatonnal. - PhD disszertáció, Eötvös Loránd Tudományegyetem, Budapest, 202 p. 
TóTH, Á. \& MÁDL-SZŐNYI, J. 2016: Scale-dependent evaluation of an unconfined carbonate system - Practical application, consequences and significance. - Karst without boundaries, IAH - Selected papers on hydrogeology 23, 199-214. https://doi.org/10.1201/b21380-17

TótH, Á. \& MÁDL-SzŐNYI, J. 2019: Where does the drinking water come from? - Interrelationship between surface water and groundwater in a carbonate area, Hungary. - Geophysical Research Abstracts 21, EGU2019-8902, 2019.

Tóth, Á., GALSA, A. \& MÁDL-SzŐNYI, J. 2020: Significance of basin asymmetry and regional groundwater flow conditions in preliminary geothermal potential assessment - Implications on extensional geothermal plays. - Global and Planetary Change 195, 103344. https://doi.org/10.1016/j.gloplacha.2020.103344

Tóth Á., HAVRIL T. \& MÁdLNÉ SzŐNYI J. 2020: Rejtőzködő vizek nyomában a Balaton térségében - Mi hiányzik a Balatonból? - In: BABINSZKi E. \& Horváth F. (szerk.) A Balaton kutatása Lóczy Lajos nyomdokán. - MFT, Budapest, 287-311.

Tóth, Á., HaVril, T., Simon, Sz., Galsa, A., SAntos F. A. M., MülLER, I. \& MÁDL-SzÓNYI, J. 2016: Groundwater flow pattern and related environmental phenomena in complex geologic setting based on integrated model construction. - Journal of Hydrology 539, 330 344. https://doi.org/10.1016/j.jhydrol.2016.05.038

Tóth, Gy., Rman N., Rotár-Szalkai, Á., KeréKgyártó, T., Szőcs, T., Lapanje A., Černák R., Remsík A., Schubert G. \& NÁdor, A. 2016: Transboundary fresh and thermal groundwater flows in the west part of the Pannonian Basin. - Renewable and Sustainable Energy Reviews 57, 439-454. https://doi.org/10.1016/j.rser.2015.12.021

То́тн, J. 1962: A theory of groundwater motion in small drainage basins in central Alberta, Canada. - Journal of Geophysical Research 67/11, 4375-4387. https://doi.org/10.1029/jz067i011p04375

То́тн, J. 1963: A theoretical analysis of groundwater flow in small drainage basins. - Journal of Geophysical Research 68/16, 4795-4812. https://doi.org/10.1029/jz068i016p04795

То́тн, J. 1970: A conceptual model of the groundwater regime and the hydrogeologic environment. - Journal of Hydrogeology 10/2, 164176. https://doi.org/10.1016/0022-1694(70)90186-1

То́тн, J. 1978: Gravity induced cross-fundamental flow of formation fluids, Red Earth Region, Alberta, Canada: Analysis, patterns, and evolution. - Water Resources Research 14/5, 805-843. https://doi.org/10.1029/wr014i005p00805

То́тн, J. 1980: Cross-formational gravity-flow of groundwater: A mechanism of the transport and accumulation of petroleum (The generalized hydraulic theory of petroleum migration). - In: RoBERTs, W. H. \& CoRDELL, R. J. (eds): Problems of Petroleum Migration. AAPG Studies in Geology 10, Tulsa, Oklahoma, USA, 121-167.

То́тн, J. 1995a: Hydraulic continuity in large sedimentary basins. - Hydrogeology Journal 3/4, 4-16. https://doi.org/10.1007/ s100400050250

Тóтн J. 1995b: A nagy kiterjedésú üledékes medencék felszín alatti vizeinek hidraulikai folytonossága. - Hidrológiai Közlöny 75/3, 153159.

Tо́тн, J. 1999: Groundwater as a geologic agent: An overview of the causes, processes, and manifestations. - Hydrogeology Journal 7/1, 1-14. https://doi.org/10.1007/s100400050176

То́тн, J. 2003: Fluid-potential patterns and hydrocarbon deposits in groundwater flow-fields induced by gravity and tectonic compression, Hungarian Great Plain, Pannonian Basin. - Journal of Geochemical Exploration 78-79, 427-431. https://doi.org/ $10.1016 / \mathrm{s} 0375-6742(03) 00024-4$

Tо́тH, J. 2009a: Gravitational Systems of Groundwater Flow - Theory, Evaluation, Utilization. - University Press, Cambridge, UK, 310 p.

Тótн, J. 2009b: Springs seen and interpreted in the context of groundwater flow-systems. - GSA Annual Meeting, 2009. október 18-21., Portland, USA.

TótH, J. \& ALMÁSI, I. 2001: Interpretation of observed fluid potential patterns in a deep sedimentary basin under tectonic compression: Hungarian Great Plain, Pannonian Basin. - Geofluids 1, 11-36. https://doi.org/10.1046/j.1468-8123.2001.11004.x

Tóth, J. \& MillaR, R. F. 1983: Possible Effects of Erosional Changes of the Topographic Relief on Pore Pressures at Depth. - Water Resources Research 19/6, 1585-1597. https://doi.org/10.1029/wr019i006p01585

URBANCSEK J. 1963: A földtani felépítés és rétegvíznyomás közötti összefüggés az Alföldön. - Hidrológiai Közlöny 43/3, $205-218$.

VARSÁNYI Z. 2000: Felszín alatti vízmozgási rendszerek elkülönítése a Dél-Alföldön kémiai és izotópos vizsgálatok alapján. Hidrológiai Közlöny 80/3, 145-156.

VARSÁNYI, I. \& Ó. KovÁCS, L. 2009: Origin, chemical and isotopic evolution of formation water in geopressured zones in the Pannonian Basin, Hungary. - Chemical Geology 264, 187-196. https://doi.org/10.1016/j.chemgeo.2009.03.006

VENDEL M. \& KISHÁZI P. 1964: Összefüggések melegforrások és karsztvizek között a Dunántúli-középhegységben megfigyelt viszonyok alapján. - MTA Múszaki Tudományos Osztályának Közleményei 32, 393-417, 33, 205-234.

WALTON, W. C. 1960: Leaky artesian aquifer conditions in Illinois. - Illinois Water Survey Report of Investigations 39, 27 p.

WANG, X. S., JIANG, X. W., WAN, L., GE, S. \& LI, H. 2011: A new analytical solution of topography-driven flow in a drainage basin with depth dependent anisotropy of permeability. - Water Resources Research 47/9, W09603. https://doi.org/10.1029/2011wr010507

ZHou, Y. \& LI, W. 2011: A review of regional groundwater flow modeling. - Geoscience Frontiers 2/2, 205-214. https://doi.org/10.1016/ j.gsf.2011.03.003

ZIJL, W. 1999: Scale aspects of groundwater flow and transport systems. - Hydrogeology Journal 7/1, 139-150. https://doi.org/10.1007/ s100400050185

ZIJL, W. 2019: Creep Flow Systems in the Earth Crust: A Complement to Groundwater Flow Systems. - Geophysical Research Abstracts 21, EGU2019-1790-3, 2019.

Zsemle F., MÁdLnÉ SzŐNYI J. \& ANGelus B. 2002: Felszíni hidraulikai rezsimjelleg térképezése az izsáki Kolon-tó környezetében. Hidrológiai Közlöny 82, 110-119.

Kézirat beérkezett:2020. 07. 19. 